\title{
THE RELEVANCE OF AL MU'ASHARAH MANUSCRIPT TO THE MILLENNIAL GENERATION OF JAVA, SUNDA, AND MINANG ETHNIC IN SPOUSE SELECTION
}

\author{
Yulfira Riza $^{1^{*}}$, Titin Nurhayati Mamun ${ }^{2}$, Syarief Hidayat ${ }^{3}$, Ikhwan $^{4}$ \\ $1^{*, 2,3,4}$ Faculty of culture sciences, Universitas Padjadjaran, Indonesia. \\ Email: ${ }^{1 *}$ yulfira17001@mail.unpad.ac.id, ${ }^{2}$ titin.mamun@unpad.ac.id, ${ }^{3}$ syarief.hidayat@unpad.ac.id, \\ ${ }^{4}$ ikhwan@unpad.ac.id
}

Article History: Received on $30^{\text {th }}$ March 2020, Revised on $24^{\text {th }}$ May 2020, Published on 22 ${ }^{\text {nd }}$ June 2020

\begin{abstract}
Purpose: This study aims to analyze the perception of the millennials of Javanese, Sundanese, and Minang in choosing a spouse, arranged marriage, and forced marriage based on a West Sumatra's ancient manuscript, al Mu'assharah by Sheikh Abdul Lațîf Shakūr.
\end{abstract}

Methodology: This research is a quantitative study using a questionnaire as a method and instrument. Based on the variables contained in the manuscript, a closed statement questionnaire was compiled and responded by 111 respondents using purposive sampling. SPSS was used for data analysis and results formulation.

Main Findings: The results show that the female's millennials still adhere to noble values in determining future husbands such as taqwa and good character, good health, broad-minded, and wise. The difference of opinion between the groups lies in the appearance of the prospective husband and the pleasure in receiving gifts. Meanwhile, the male's millennials also want a future wife who has good morals, comes from a good family, and has a beautiful face. The differences of opinion of the groups are in the age and status variables of the prospective wife. In terms of arranged marriages and forced marriages, all refused to be married to people they unknown, even though the parents are the ones who forced them. They choose ta'aruf as a method of introducing a spouse before marriage.

Implications/Applications: The findings of this research can be helpful for readers in understanding the phenomena of marriages in Islam and characteristics prefer while choosing a spouse.

Novelty/Originality of this study: The number of sites and online matchmaking accounts both Muslim and non-Muslim has an influence on Indonesian Muslims who have diverse tribes. Dating selection is not only based on pleasure through the appearance and profile displayed online, but the in-depth search is required. This study has highlighted matchmaking preferences in Javanese culture and also analyzed aspects of Islam based on the work of scholars then compare it with other ethnicities in Indonesia.

Keywords: Matchmaking, Millennial Generation, Ethnicity, Islamic Perspective, Spouse Preferences.

\section{INTRODUCTION}

There is an old proverb that says"Tak kan lari Gunung dikejar (The mountain will not run if chased)". In its development, it was added by the millennial generation with "Tak akan sampai Kalau take Jalan(One will not arrive if one does not go)". This saying means that one's future spouse is determined by God, thus will not go anywhere and will come in time. The addition of the proverb implies that one's mate will indeed not go anywhere, but if not sought, their mate will not be found and obtained.

The millennial generation who is familiar with easily getting things through their fingertips via a smartphone has also their way of finding their future spouse, in such that it is not something difficult. Nowadays, there are many social media sites and networks that offer online dating services. From your fingertips, your future mate will be easy to find and obtained, and even according to your dream criteria.

The administrators of these matchmaking sites also act as matchmakers who are willing to match each prospector (Brown, 2011). Online dating sites that have existed in several countries such as BharatMatrimony.com in India is beginning to erode the family-arranged matchmaking tradition, MyGamma which was pioneered in Singapore has linked people from Asia to Africa, the GeneTree.com site and Anchestry.com which connects people from around the world by looking for DNA matches, and Wang Hun, an application developed in China and packaged in the form of a wedding game. The Wang Hun application turned out to have a huge impact on the marriage life of the Chinese people, thus causing many official marriages to end in divorce (Brown, 2011; Al-khresheh, Khaerurrozikin, \& Zaid, 2020). Other online dating sites such as eHarmony.com, PlentyOfFish, and Match.com have also managed to match people by relying on their interest algorithm $(\mathrm{KaO}, 2016)$. During the development of these sites, another matchmaking application called Tinder emerged, that gave male and female users access to greet, get to know each other, and then get married. Because one of its founders, Withney Wolfe, was harassed by one of the founders of Tinder, she later established a rival site, called Bumble (Summers, 2014).

The comparison of Tinder and Bumble has been investigated by Bryden (2017) in his thesis using the theory of Uses and Gratifications Theory (UGT) (Bryden, 2017). This study involved 190 respondents aged 18 years and over who lived 
around Eastern Washington University to measure differences in representation among online dating participants based on UGT. This research yields reasons why people use online dating applications to seek attention, increase selfconfidence, and surf to spend time. Gender representation in dating is determined by the user himself.

In India, whose marriages are often arranged by families, it is now also inseparable from matrimony online dating sites, which becomes quite significant. These sites are IndiaMatrimony.com, jeevansathi.com, BharatMatrimony.com, and Shaadi.com. The use of these sites aside from being a matchmaking event is also considered a symbol of the modernity of the young Indian generation (Mishra, Monippally, \& Jayakar, 2013). For Muslims, there are many online matchmaking sites that are also developed, including SingleMuslims.com and MuslimMatrimony.com. This site uses an Islamic religious identity that wants marriage as the result not an intimate relationship like other secular online sites. Analysis of this Muslim online dating site produces religious values, culture, and Islamic principles that are still firmly attached to its users so that conversations are not only motivated by mere lust (Tiller, 2018; Yang \& Chang, 2017; Sintang \& Hambali, 2018; Saadia, 2015).

In Islam, guidance is arranged in the form of ta'aruf, a media for the introduction and search of matchmaking for generations of Muslims following the Islamic law (Hidayat \& Wardana, 2018). Men and women do not meet in person and then make an appointment, but are mediated by a companion whom they call murabbi and murabbiya (Asyari \&Abid, 2016). In Indonesia, in addition to the ta'aruf process through the role of murabbi and murabbiya, there is also an online ta'aruf site called rumahtaaruf.com which also involve mediators in their introductory processes (Pujasari \& Mardianti, 2016). Besides, social media can also be a ta'aruf media for the millennials, such as through Instagram account @ ta_aruf_nikah. This account is managed in a closed manner so that the series of conversations between people who will meet is supervised directly by the admin. Through this account, many followers have successfully married (Saifullah, 2018; Ammon, 2004; Bell, 2005; Blachman, Tangel, \& Ball, 2004; Cook, 1991; Fairclough, 1989).

The number of sites and online matchmaking accounts both Muslim and non-Muslim, of course, more or less has an influence on Indonesian Muslims who have diverse tribes. Dating selection is not only based on pleasure through the appearance and profile displayed online, but the in-depth search is required. This challenge has long been written in Nusantara texts, especially those from Minangkabau namely al Mu'āsharah. This manuscript was written by one of the Nusantara scholars, Shekh Abdul Lațif Shakūr (hereinafter written as Shakūr), a scholar from Balai Gurah, West Sumatra. He took special attention to issues regarding gender and morals. Many of his writings are related to both of these issues. In addition to al Mu'āsharah, there is Dunia Perempuan (Women's World) which specifically discusses women (Riza \& Sandora, 2019; Hamers \& Blanc, 2000; Heath, 2005; Wekke \& Hamid, 2013; Godwin-Jones, 2005).

This study aims to analyze the profile of women or men desired by millennials as their soul mates and their perceptions of arranged marriages and forced marriages. The analysis is based on the role written by Shakūr in al Mu'āsharah which is analyzed philologically. This research involves the millennial generation of men and women who only come from Javanese, Sundanese and Minang tribes. The selection of these three tribes is based on the first two tribes, which are the two largest tribes in Indonesia, while the Minang tribe was taken as samples because this manuscript was born amid Minangkabau culture which is thick with customs and marriage arrangements by the family. Wahyudi's (2012) research on matchmaking in the perspective of ethnic Javanese had previously been done by interviewing a girl who was very shy to have an arranged marriage. Wahyudi's (2012) conversations were limited to online conversations via Yahoo messenger in 2010 based on Dhofier's opinion about profession, wealth, religion, and education considered as status for the people of Java. The result was that matchmaking in ethnicity is indeed based on Islam and Javanese culture in general (Wahyudi, 2012; Askuri \& Kuipers, 2019; Bunton \& Brewer, 2012). Meanwhile, this research strives to further analyze aspects of Islam based on the work of scholars then compare it with other ethnicities in Indonesia.

\section{Research Gap and Objectives}

As discussed earlier, matchmaking has become challenging for individuals in such a competitive era. With time people are more inclined to find the best spouse with all desired characteristics and this leads them to matrimonial sites. Although matrimonial sites give access to many candidates, yet the possibility of fraud and fake information remains. tribes. Dating selection is not only based on pleasure through the appearance and profile displayed online, but the indepth search is required, which becomes very challenging at times. This urged the authors to investigate the preferences of males and females of Indonesia in spouse selection. The objectives of this study are

i) To analyze the profile of women or men desired by millennial as their soul mates.

ii) To analyze their perceptions of arranged marriages and forced marriages.

\section{MATERIAL AND METHOD}

The object of this study is the manuscriptal Mu'āsharah in Ikhtiyāru al ziwāj and Ikhtiyāru al zaujah (soul mate) sections. These two discussions are published on pages 67 and 68 of the manuscript al Mu'assharah, a manuscript written in 1924 by a Muslim scholar from Balai Gurah Agam Regency, Shekh Abdul Lațif Shakūr. This manuscript is 
written in a recto-verso format using plain paper that has no lines, in black ink, without rubrications, and measuring 13.5 x $20 \mathrm{~cm}$. This manuscript is written in 70 pages with 24 lines per page in the Arabic Jawi script. In some pages the manuscript was discovered corrupt; ink and pages ate by termites interfere with the reading of the text. The manuscript, written in three non-bound curates, contains 39 short articles which can be grouped into (1) the importance of marriage; (2) matchmaking; (3) preparation for marriage; (4) advice stories for and about women; (5) marital relations; (6) husband and wife rights and obligations in the household; (7) women from other countries; and (8) secrets to maintaining physical beauty. This paper will focus on discussing the second group of articles about mate selection.

Although this text has been written for almost a century, its contents still have relevance to today's life because the Islamic studies discussed in this text are valid for all time. The guidelines that were written by ulama of the past is the main patron for facing the future.

To see its relevance, this study involved 111 voluntary respondents consisting of 72 women and 39 men. All respondents were millennials aged 19 to 30 years from the Minang, Sundanese or Javanese ethnic group. Javanese and Sundanese were taken as samples in this study because these two tribes are the two major tribes with the largest population spread across Indonesia and the world. The Minang tribe was subsequently used as a sample because the manuscript of al Mu'äsharah originates from there. This research attempts to prove that the period of nearly a century has not made many changes in the culture and perspectives of the millennial Muslims in terms of mate selection. This research involves three tribes in Indonesia in looking at the profile of their future husband or wife. The three tribes are Javanese, Sundanese, and Minang. With different cultural and environmental backgrounds, it is expected that the results will be more interesting and important to explore.

This study uses the questionnaire method by making the questionnaire as an instrument for data collection. Arikunto (2013) emphasized that the questionnaire is used to mention the methods and instruments used in a study (Arikunto, 2013). The questionnaire distributed was a closed, direct answered questionnaire, and took the form of multiple choice. All questions must be answered by the respondents in such that no questions were left blank. The questionnaire was arranged by specifying the variables contained in the manuscript al Mu'āsharah about Ikhtiyāru al ziwāj and Ikhtiyāru al zaujah. At this stage, eight variables were produced. Based on these variables, indicators are set to be achieved to further produce a grid of questions. This questionnaire is then used as a closed questionnaire or questionnaire as an instrument. The questionnaires were distributed online at the link http://tiny.cc/putputri for questionnaires to be filled in by female respondents and the http://tiny.cc/ksputra link for male respondents. Questionnaires were spread randomly in such that the sample taken is purposive sampling with the prerequisite of males or females aged 19-30 years old, unmarried, and originates from the Javanese, Sundanese, and Minang tribe. Because all the statements in the questionnaire must be responded to, no statement has been missed. After that, each questionnaire was processed to separate the opinions of respondents from Javanese, Sundanese and Minang ethnic groups to analyze differences in their perceptions in choosing a mate. This research has a duration of four weeks starting from questionnaire preparation, questionnaire distribution, data processing and collection, data analysis, and presenting it into articles.

\section{RESULT}

\section{Millennial Women Respondents}

The total number of female millennial respondents who filled out the questionnaire was 72, aged between 19 to 30 years with the age range of 19-22 years as many as 44 people, aged 23-26 years as many as 26 people, and aged 27-30 years as many as 2 people. A total of 22 of these respondents are Minang, 21 are Sundanese, and 29 are Javanese. The respondents were composed of 56 students, 13 private employees, and 3 unemployed.

Two parts of the questionnaire must be filled out by the respondents on the choice of a mate and the marriage consent questionnaire. The matchmaking questionnaire has eight variables that are responded by respondents with 46 items that are answered through the scale 'strongly agree', 'agree', 'disagree', and 'strongly disagree'. Meanwhile, the marriage consent questionnaire consisted of 2 variables containing 9 statements to respond. The entire variables that were posed to the female respondents were based on the spouse selection criteria and marriage approval, that was published by Shakur in the manuscript al Mu'āsharah on the Ikhtiyāru al ziwāj section. These variables include observance of prayers, honesty, physical health, wisdom, breadth of knowledge, the height of morals and character, good looks, and wealth. Variables and items for matchmaking statements submitted to female and male respondents have differences. However, specifically for the marriage consent section, both types of respondents were given the same statement item. The results of this study indicate the character of the prospective husband who is preferred by the millennial generation of women.

\section{a. Spouse Selection}

The adherence to prayer is the first variable in the mate selection section for the female millennial generation. This variable is measured by three indicators: determining a prospective husband who is devout to praying, proving his adherence to prayers, and supporting him to be more devout. These three indicators are measured through five statements. The three statements that were most desired by the respondents are the desire to have a husband that is 
devout in prayers; praying in accordance with its time as a form of adherence to prayer, and giving support for the husband in the future to participate in doing sunnah prayers. One hundred percent of the Minang respondents responded 'strongly agree' to the first two statements, followed by the Sundanese and Javanese respondents, each of whom respectively responded $95 \%$ and $93 \%$ 'strongly agree' to the first statement while the rest answered 'agree'. The second statement was responded 'strongly agree' by $86 \%$ of the Sundanese and $69 \%$ of the Javanese, while the rest answering to 'agree'. The third statement was responded 'strongly agree' by $86 \%$ (Minang); 69\% (Java); and 67\% (Sundanese) while the rest had answered 'agree'. The following graph is an illustration of a response to the first statement.

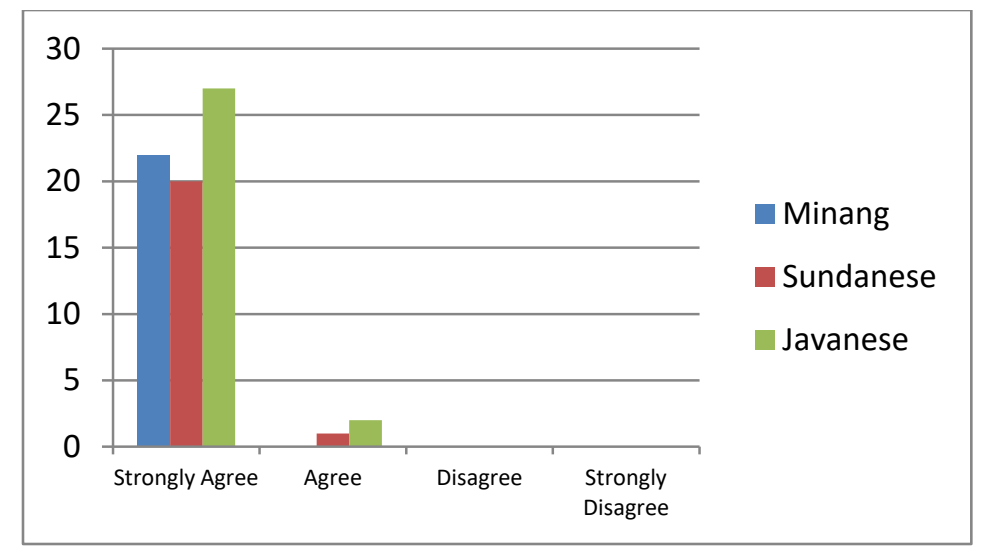

Figure 1: I Want a Prospective Husband Who is Devout to Praying

Source: Designed by the author

The statement of desire that the husband should lead prayers is strongly desired by the majority of respondents with the percentage of $86 \%$ of the Minang group; $72 \%$ of the Javanese group; and $48 \%$ of the Sundanese group. This statement was also disagreed by a small proportion of respondents from the Javanese and Sundanese, namely $4 \%$ and $14 \%$. One negative statement is that 'respondents will not be happy if their prospective husbands always carry out sunnah prayers' were'strongly disagreed' by the three groups of respondents (73\%, Minang; 62\%, Javanese; and 57\%, Sundanese). As many as $7 \%$ of the Javanese agreed to this statement.

The second variable measured is honesty. This variable is measured by one positive statement and three negative statements. The positive statement is to prefer a frank man and the negative statement is 'unhappy with a man who is too straightforward'; 'happy with men whose words and actions are not in harmony'; 'happy if the prospective husband can argue for every lie'. The positive statements were answered 'strongly agree' by $86 \%$ of the Sundanese respondents; $77 \%$ of Minangs; and 59\% of Javanese respondents. Negative statements that are not happy with men who are too forthright were answered diversely by each ethnic group. However, the three tribes still largely chose not to agree with the percentage of $68 \%$ of the Minangs; $62 \%$ of the Javanese; and $43 \%$ of the Sundanese.

The second negative statement was also responded to 'strongly disagree' by Sundanese, Javanese, and Minang tribes as much as $48 \%$; $48 \%$; and $68 \%$ respectively. Meanwhile, the third negative statement was responded to 'completely disagree' by each respondent, as can be seen in the following graph:

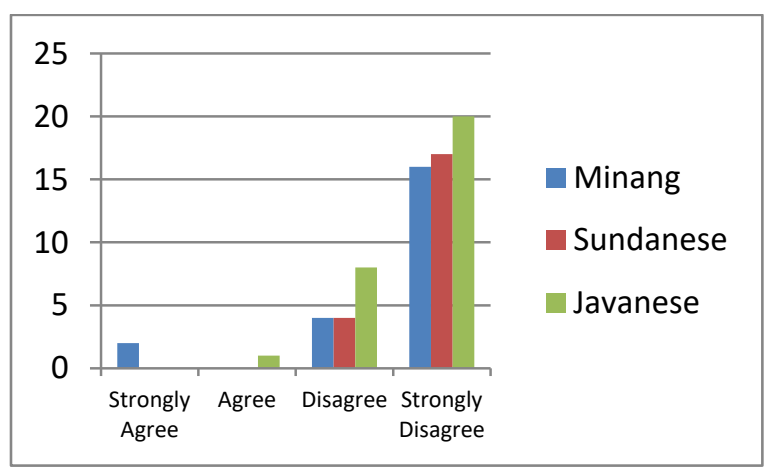

Figure 2: I Like Men Whose Words and Expressions are often out of Tune

\section{Source: Designed by the author}

The third variable measured in this study is physical health that is responded in three statements. The first statement is about dietary management as a sign of a healthy body, which are answered 'agree' by $72 \%$ of the Javanese; $67 \%$ of the Sundanese, and $59 \%$ of the Minang tribe. The second statement is 'not too concerned with the height and weight 
proportionality' was responded equivalently between those who agreed and disagreed. $68 \%$ of the Minang respondents agreed, while $27 \%$ disagreed; $45 \%$ of the Javanese agreed while $38 \%$ disagreed; while $38 \%$ of the Sundanese agreed and $33 \%$ disagreed. The third statement is "male smokers looks cool' were responded "strongly disagreed" by most respondents such as can be seen in the following graph:

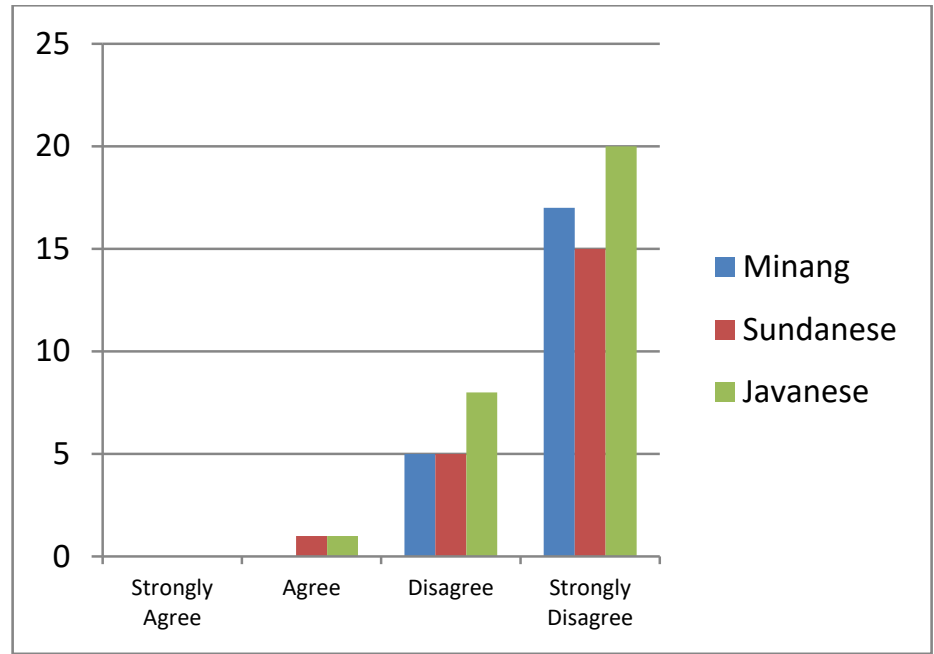

Figure 3: Male Smoker Looks Cool to Me

Source: Designed by the author

The wisdom of the prospective husband is the fourth variable proposed in this research instrument. This variable relates to the way a man believes and responds; their style of talking to others; empathy towards complaints; and caring for the social environment. Statements such as the desire of the respondent towards men who speak firmly and clearly; happy with men who appreciate the opinions of respondents; happy with men who can provide solutions to problems encountered; and felt valued if men were able to listen to their complaints were strongly desired by a dominant number of respondents, as many as $69.4 \% ; 55 \% ; 75 \% ; 69.4 \%$. Two negative statements were raised in this variable: the respondent was not happy if her future husband was too concerned about her social environment and the respondent did not want her future husband to try to get to know the respondent's friends. The first negative statement was disagreed by respondents from Javanese ethnic as much as 76\%; Minang 73\%; and Sundanese 52\%. However, 33\% of Sundanese respondents responded 'strongly disagree' with this statement. The same response was obtained for the second negative statement, such as can be seen in the following graph:

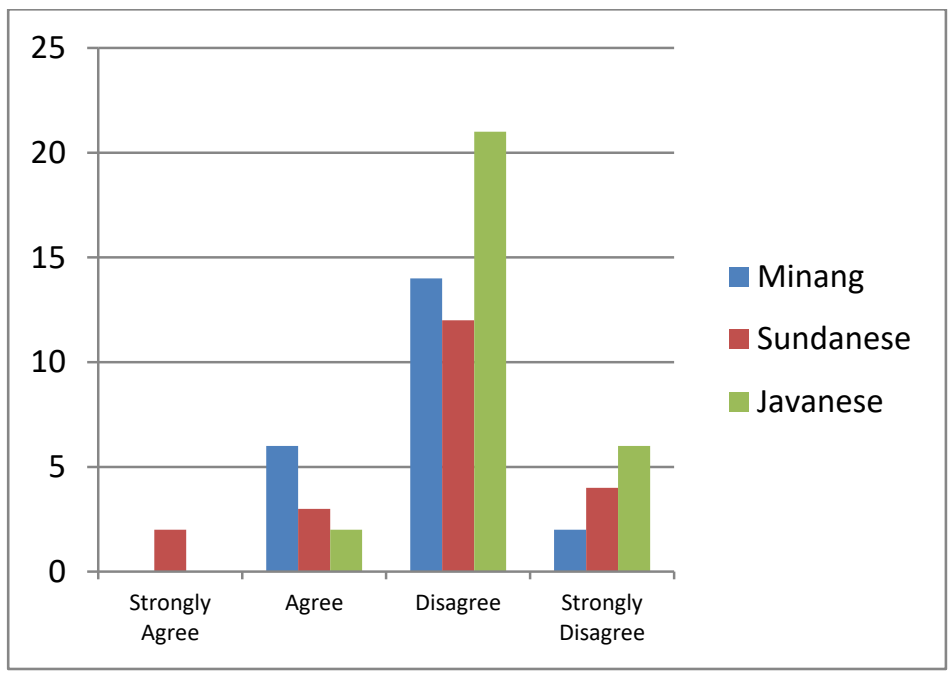

Figure 4: I Don't Want my Future Husband to Try to Get to Know My Friends

Source: Designed by the author

The fifth variable is the breadth of knowledge, as measured by a statement on their passion to read and topics of discussion. Based on the results of the questionnaire, respondents were happy with men who liked to read and did not refuse to discuss matters that are related to technology and politics. The following graph is the response of men that has a passion for reading: 


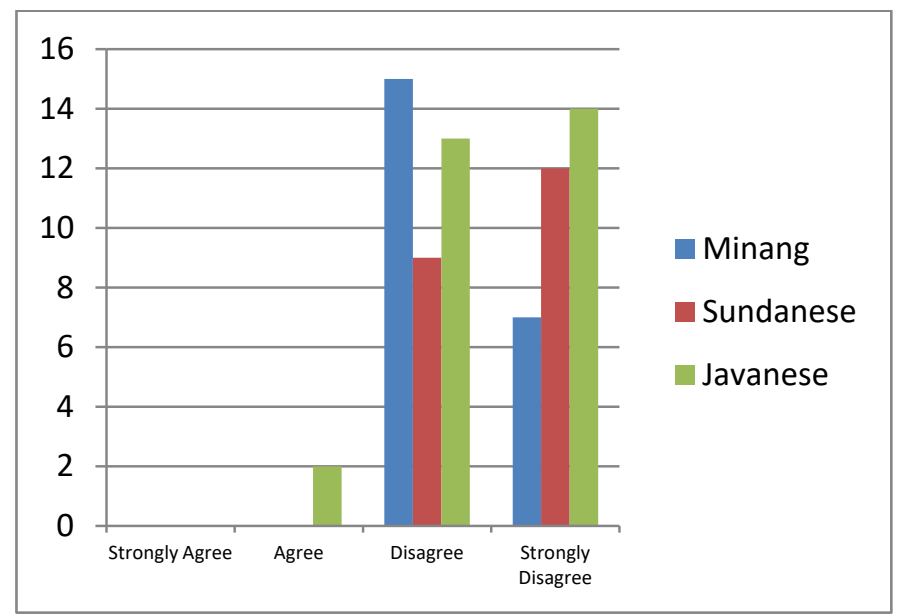

Figure 5: I Am Not Happy if Men have a Fondness for Reading

Source: Designed by the author

Topics related to technology turns out to be the most preferred topics to be discussed by a man, with as much as $71 \%$ of the Sundanese, $68 \%$ of the Minang, and $66 \%$ of the Javanese responding positively. Meanwhile, the topic of politics was favoured by Sundanese respondents as much as $86 \%$ and Javanese as much as $66 \%$. Only $45 \%$ of the Minang respondents liked political topics while $46 \%$ disliked it.

Variables that have more statements are variables on morality and character. This variable has three indicators, which are: showing good courtesy in speech, showing respect, preventing oneself from deeds that are not blessed by God, and respecting the opposite gender. Indicators which show good manners in speeches measured by the statement 'always cutting the opinions of others is a form of toughness'. All respondents mostly disagreed to this statement $(55 \%$ of the Minang tribe; $48 \%$ of the Sundanese, and $48 \%$ of Javanese). The second indicator is measured by the statement reflecting the wishes of the respondents that her future husband will respect her family as he respects his own family. This statement is dominated by respondents who 'strongly agreed', with an amount of 95\% (Sundanese respondents; 95\% Minang respondents; and 86\% Javanese respondents).

The third indicator is to prevent acts that are not approved by God in the form of four statements to respond. These statement concerns safekeeping of one's eye-sight, socializing of a prospective husband with his female friends, gathering at night clubs, and the desire for corruption. Regarding the problem of gatherings made by the prospective husband at the nightclub with his friends and the problem of corruption even though it was done in a state of urgency, respondents from the Minang, Sundanese and Javanese tribes agreed to answer 'strongly disagree'. Specifically, at nightclub meetings, $100 \%$ of Sundanese respondents answered 'strongly disagree' as can be seen in the following graph:

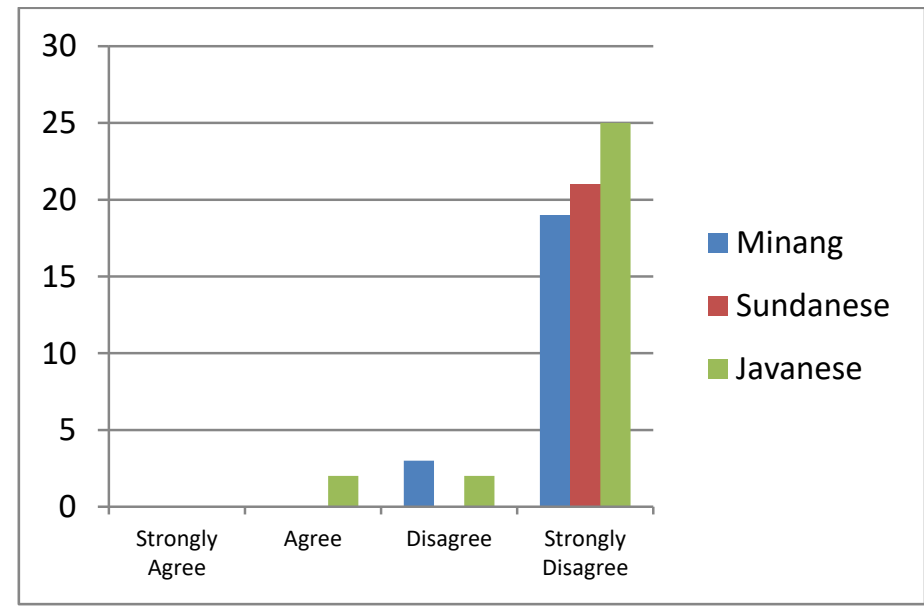

Figure 6: I Don't Mind if my Future Husband often Holds Meetings with His Friends at Night Clubs

Source: Designed by the author

Differences of opinion occurred towards the two other statements in this indicator, which concerns the future husband's female friends. Respondents from the Minang and Javanese ethnic group gave disagreement responses of as much as $59 \%$ and $55 \%$ respectively. Sundanese respondents chose more 'strongly disagree' answers compared to 'agree' with only $48 \%$ and $28 \%$ respectively. More details can be seen in the following figure: 


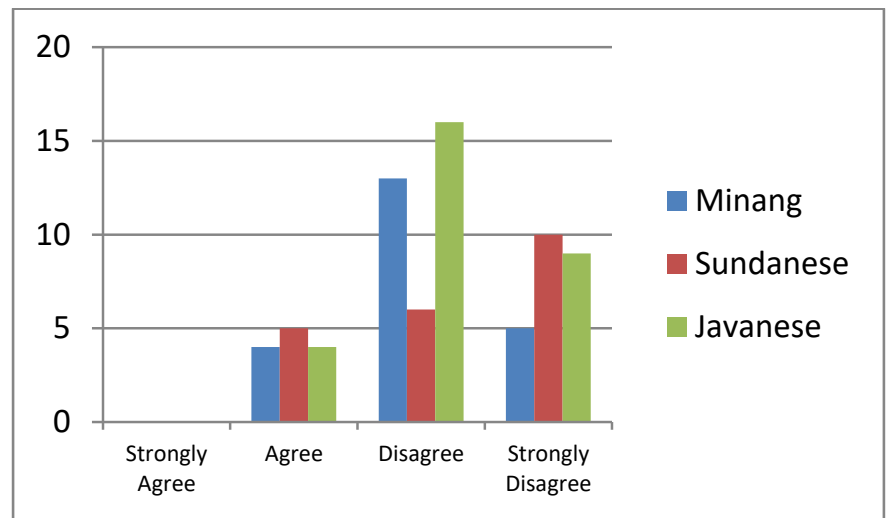

Figure 7: It Doesn't Matter if My Husband has Many Female Friends

Source: Designed by the author

Similar responses also occur with statements about men who kept eye contact while talking to a female. Respondents from the Sundanese and Javanese ethnic groups prefer answers that 'strongly disagree' for as many as $62 \%$ and $48 \%$, while respondents from the Minang ethnic group prefer the respond to agree as much as $50 \%$. This variable also asked about respecting the opposite gender. To measure it, three statements were proposed which produced varied responses from each respondent. Although in general the three tribes answered 'strongly disagree' and 'disagree' if the prospective husband teases with sweet words, there are also among those who answer 'agree' such as can be seen in the following graph:

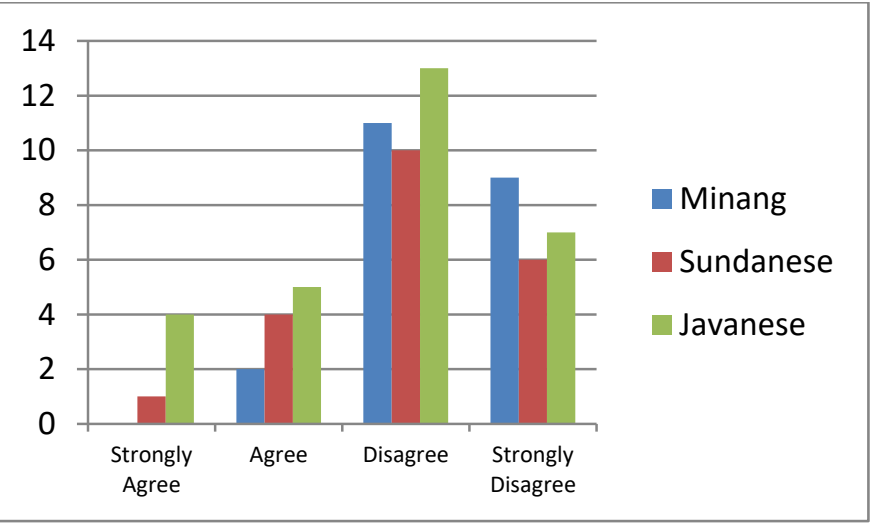

Figure 8: I am Happy if, in Our First Introduction, my Future Husband Teases me with sweet words

Source: Designed by the author

The same response also occurred to the statement 'I am happy if my future husband holds my hand even though we are not married'. Most respondents answered 'strongly disagree', disagree, and agree. But there is one Sundanese respondent who answered 'strongly agree' if her future husband holds her hand even though they are not married yet. The following data is illustrated in the graph below:

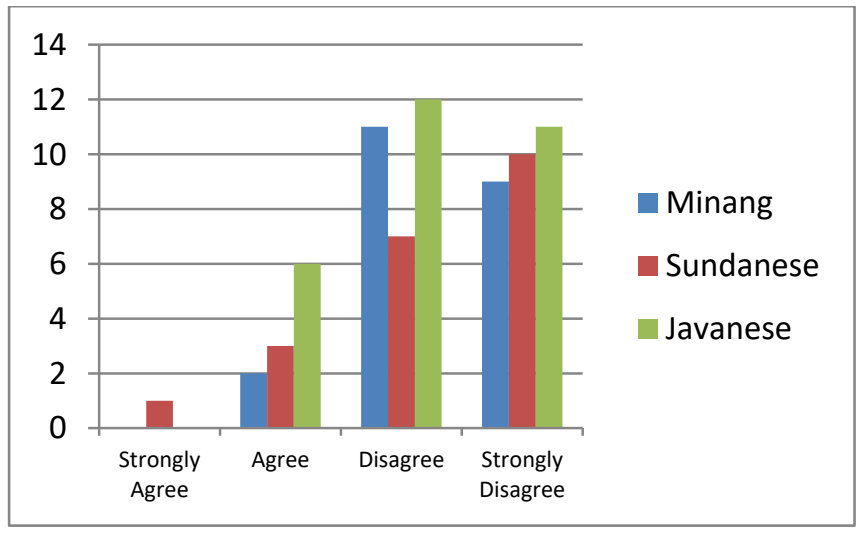

Figure 9: I am Happy if my Future Husband holds my Hand in any place even though we are not Married

Source: Designed by the author 
The seventh variable is consideration towards the physical appearance such as body posture, a good looking face, and smooth hair. Based on the results of the questionnaire, most Javanese respondents disagree with these three factors in choosing a prospective husband with a percentage of $48 \%, 41 \%$, and $55 \%$ respectively, although some agreed, with the percentage $31 \%, 35 \%$, and $38 \%$ respectively. A 'strongly agreed' response was not found for the choice factor of men with shiny and smooth hair. Minang ethnic respondents considered posture and smooth-haired men to be their husbands (55\% and 64\%), but do not agree to make a handsome face a priority (59\%). This was unlike the Sundanese who agreed to find a handsome husband, as much as $52 \%$ of respondents, but does not agree to consider the posture as consideration (52\%) and also do not agree with men that have smooth and shiny hair (52\%). More details can be seen in the following graphs:

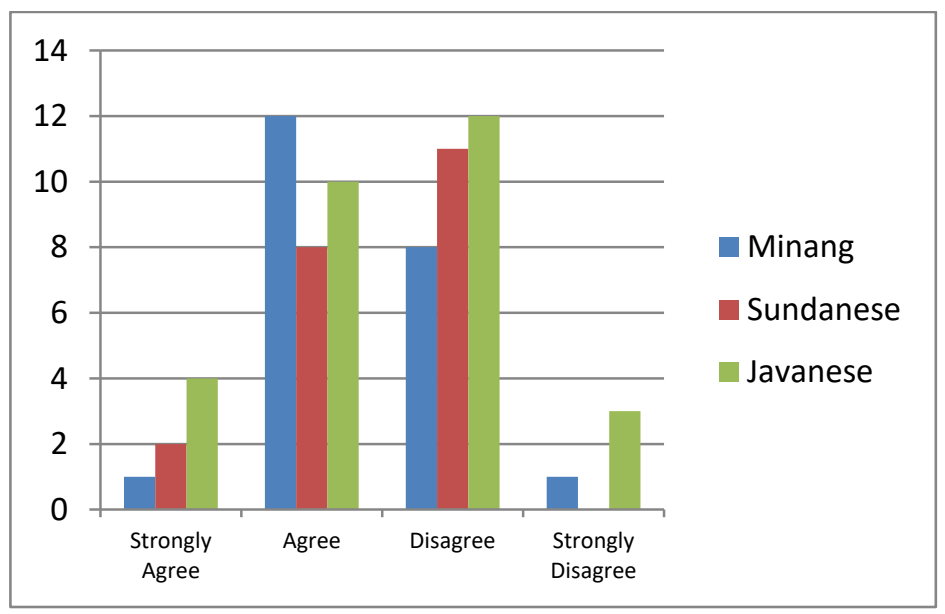

Figure 10: Body Posture and Stature are my Considerations in Choosing a Husband

Source: Designed by the author

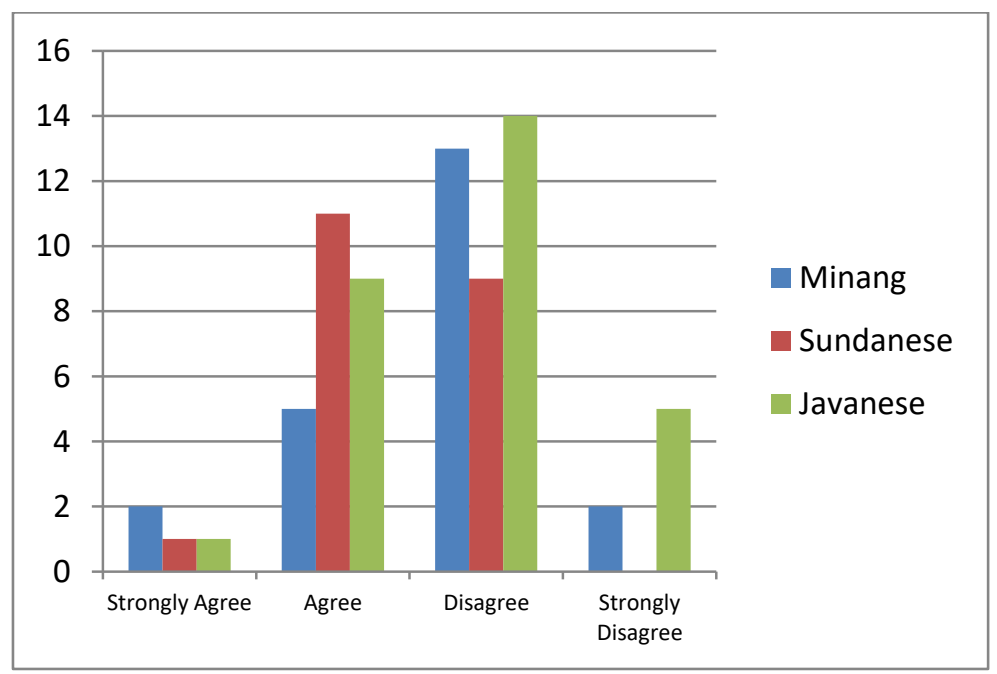

Figure 11: I Will Only Marry a Man who has a Handsome Face and that is Pleasing to the Eye

Source: Designed by the author

Wealth and generosity in giving gifts become the last variable in the matchmaking section that was asked in this questionnaire. To measure it, four statements were proposed, including 'Much wealth and generous in giving gifts is a priority in choosing a husband.'; to win hearts, respondents are happy to be given gifts; luxury gifts from men is a form of appreciation to respondents, and men who like to give gifts usually have ulterior motives. The four statements were mostly answered in disagreement by respondents with Javanese ethnicity of 59\%, 48\%, 48\%, and 72\%, respectively. The Sundanese and Minang ethnic respondents have the same negative response to the first and second statements but differ from the third and fourth statements. As many as 52\% of Sundanese respondents agree with the statement 'Luxury gift is a form of appreciation for a man' while as many as 59\% of the Minang respondents preferred to disagree with that opinion. The fourth statement, likewise, has as many as $45 \%$ of Minang respondents who agreed with the statement 'Men who like to give gifts have ulterior motives', but Sundanese respondents choose to disagree with these opinions $(67 \%)$. The following graph includes more details. 


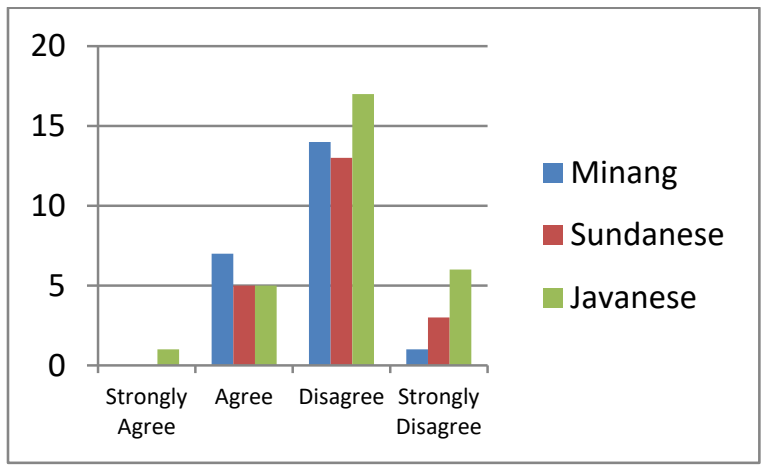

Figure 12: Much Wealth and Generous in giving Gifts is my Priority in Choosing a Husband

Source: Designed by the author

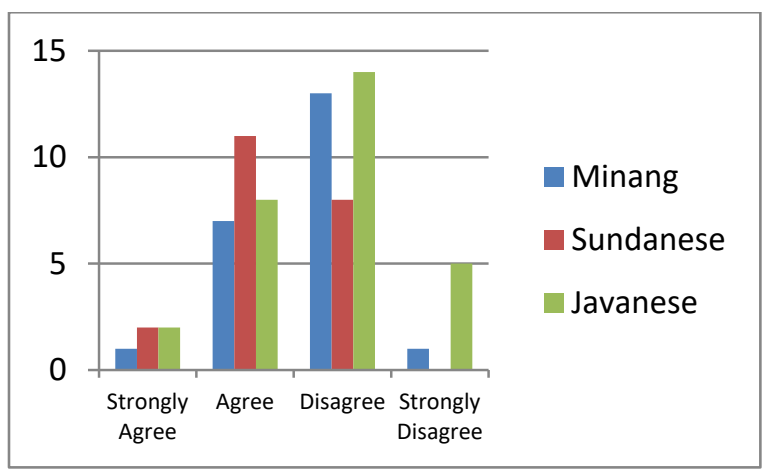

Figure 13: A Luxurious Gift from my Future Husband is a Form of Appreciation to Me

Source: Designed by the author

\section{b. Marriage Approval}

The second part of the questionnaire that must be filled out by the female millennial generation is about marriage approval. In this section, two variables were asked, namely the introduction and coercion of marriage. The indicator in the introductory variable is to determine the form and format of introduction as measured through five statements: choosing to date before marriage; choosing ta'aruf processions to get to know each other; willingness to an arranged marriage with an unknown man; must know the prospective husband in an arranged marriage; and allowing the prospective husband to investigate the respondent personally through their close friends as part of the introduction. The first statement was responded with various answers from each respondent. Java and Minang ethnic respondents mostly answered 'agree' to not be paired with someone that they do not know. Each response were $41 \%$ and $36 \%$, while the Sundanese respondents chose 'quite agree' with the opinion, for as much as $38 \%$. However, many respondents answered that they did not agree with arranged marriages. The following graph illustrates this.

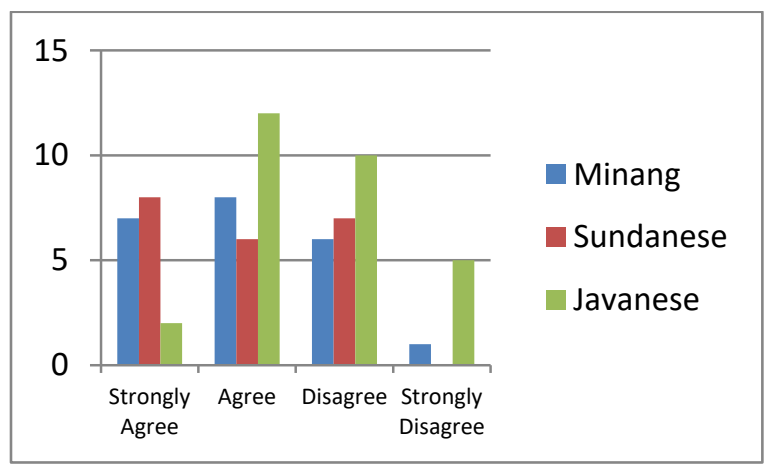

Figure 14: Not Willing to have an Arranged Marriage with Someone Unknown

Source: Designed by the author

Ta'aruf as a form of introduction before marriage was also agreed by the majority of respondents, as many as $48 \%$ of Sundanese, $50 \%$ of Minang, and 55\% Javanese. However, some respondents disagreed, namely $14 \%$ of Sundanese, $17 \%$ of Javanese, and $23 \%$ of Minang. However, as many as $5 \%$ or 1 people from the Sundanese tribe chose to 'strongly 
disagree' for the ta'aruf process. Dating was also disapproved by the majority of respondents, although some agreed, $24 \%$ of Sundanese, $27 \%$ of Minang, and $34 \%$ of Javanese respondents.

All respondents have the same opinion to agree and 'strongly agree' with the fourth and fifth statements. As many as $62 \%$ of Javanese respondents, 59\% Minang respondents, and 52\% of Sundanese respondents agreed that they have to know their prospective husbands first. For the statement 'Allowing the prospective husband to personally investigate the respondent through their close friends', the respondent also stated their agreement as much as $76 \%$ of the Sundanese, $55 \%$ of the Javanese, and $45 \%$ of the Minang. However, it was also found that $41 \%$ of the Minang, $17 \%$ of the Javanese, and $5 \%$ of the Sundanese disagreed with this statement.

The second variable that is asked in the second part of this questionnaire is about forced marriage. Respondents were asked for their opinions on forced marriage by giving three choices of answers, namely (1) could not refuse the marriage agreement; (2) was asked to marry someone whose appearance and stature is not favoured; and (3) was arranged in marriage and was required to marry a stranger. Minang and Javanese respondents prefer the first answer with a percentage of $50 \%$ and $48 \%$ respectively while Javanese respondents choose the third answer which is as much as $62 \%$. When asked about wali mujbir, most respondents answered that they did not know, namely $71 \%$ of Sundanese, $59 \%$ of Minang, $52 \%$ of Javanese. For two statements that are related to the father or mother who forced their daughter into a marriage agreement, respondents gave various answers, but mostly negative answers. Respondents with Sundanese and Javanese ethnic groups prefer not to agree to be forced to marry by their fathers and mothers, $48 \%$ for Sundanese and 55\%, and $62 \%$ for Javanese, respectively. Unlike the case with respondents from the Minang tribe who prefer to agree in forced marriage, as many as $36 \%$ and $41 \%$. More details can be seen in the following graph.

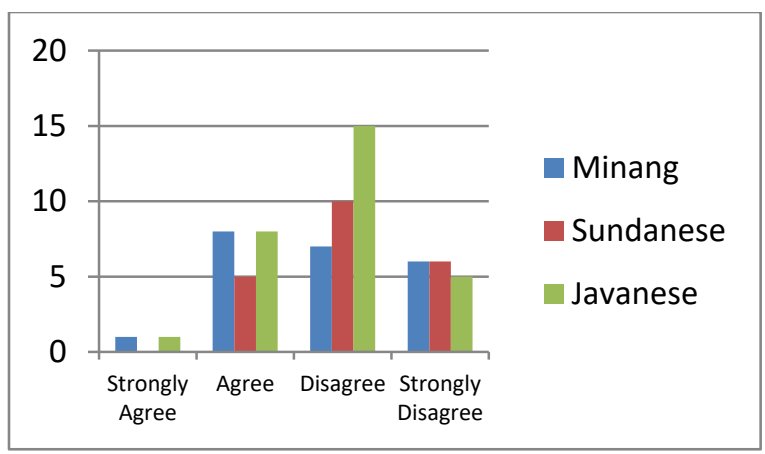

Figure 15: If My Father insisted that I Marry a Man of His Choice, I Would Still Accept it Even though I Don’t Recognize Him

Source: Designed by the author

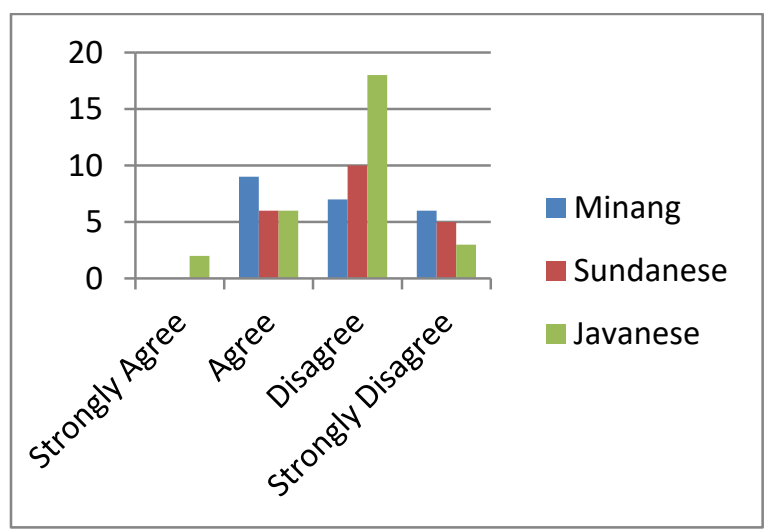

Figure 16: If my Mother Forces me to marry the Man of her Choice, I Will Still accept it even though I don't like it

Source: Designed by the author

\section{Millennial Men Respondents}

Similar to female respondents, male respondents involved in this study were also from the Minang, Sundanese, and Javanese ethnic groups, but in a smaller amount because only 39 males had responded to the questionnaire. The male respondents had an age range of 19-22 years as many as 11 people, ages 23-26 years as many as 19 people, and ages 2730 years as many as 9 people. They were given a questionnaire with two classifications of statements namely spouse selection and marriage approval. As have been mentioned before, the statement items in the second classification are the same as those given to female respondents, while the statement items in the first classification are different. This is due 
to differences in variables measured based on the manuscript al Mu'āsharah in the Ikhtiyāru al zaujah section written by Shakūr.

The mate selection variable measured in this research instrument consists of eight parts namely morals, descent, age, wealth, height, career, education, and appearance. Meanwhile, the variables for the classification of marriage approval are the introduction and approval of marriage.

\section{a. Spouse Selection}

The character of a woman is the first variable measured in this questionnaire. Testing for this variable uses four indicators, which shows softness in speech; display gestures that are friendly to the speaker; choose clothes that are polite and Islamic; and social interaction. The first indicator consisted of the statement: 'I am interested in women who speaks in a soft and friendly manner' which was very agreed by all respondents with $86 \%$ of Javanese, $84 \%$ from Sundanese, and $83 \%$ from the Minang ethnic group. The second statement is the desire of respondents to find a spouse whose character is far better than themselves. Most respondents responded 'agree' to this statement such as can be seen in the following graph.

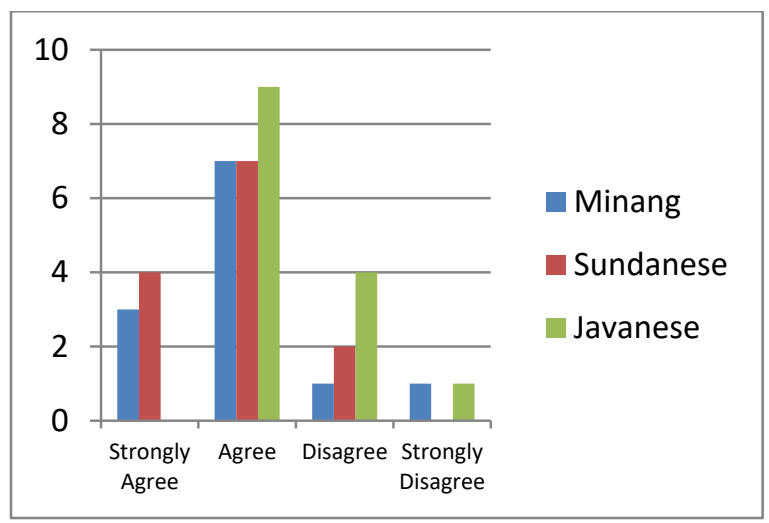

Figure 17: I want my Wife to be a Woman Who is higher in Character than Me

Source: Designed by the author

The second indicator is measured by three statements consisting of one positive statement and two negative statements. The positive statement is being happy of women who give full attention to the conversation, which is responded with 'strongly agree' by the majority of respondents, namely $50 \%$ of the Minang tribe; $54 \%$ of the Sundanese, and $64 \%$ of Javanese respondents. The negative statements disliking women who like to smile, which is responded in 'disagree' by almost all respondents, namely $85 \%$ of the Sundanese; $67 \%$ of the Minang; and $43 \%$ of the Javanese respondents. As many as $36 \%$ of the Javanese respondents answered 'strongly disagree' to this statement. The second negative statement in this indicator is the dislike for women who kept eye contact when the respondent is talking. There are differences in responses between the three ethnic groups. Respondents from the Javanese and Sundanese ethnic groups responded 'disagree' with these opinions by $72 \%$ and $69 \%$ respectively. Meanwhile, as many as $50 \%$ of respondents from the Minang group did not like women who kept eye contact during discussions

The third indicator measured in this variable is dressing in a polite and Islamic manner. Most respondents answered "yes" to the statement, that one of the criteria in choosing a wife is in terms of how she was dressed. When given a statement about women who wears long pants and sporty outfit, the 'disagreed' response was mostly chosen by Sundanese respondents at $77 \%$ while the Minang and Javanese chose to agree with this opinion respectively $42 \%$ and $43 \%$. However, when asked for opinions about women who were dressed scantly to be wives, respondents from the Javanese and Minang tribes mostly answered 'strongly disagree' as many as $72 \%$ and 54\% while Sundanese respondents mostly answered 'disagree' (54\%) and the rest had 'strongly disagree' as much as $46 \%$. Various answers were given by respondents when asked for opinions about not being too fond of women who wear long robes and veils. This statement was mostly dissented by Sundanese respondents (54\%), followed by Minang respondents by $50 \%$. Meanwhile, Javanese respondents prefer to 'strongly disagree' as many as $43 \%$.

The fourth indicator tested in this questionnaire is on socialization and the social environment of a woman. The first statement is preferring a woman who socializes with the male friends of the respondent. This statement is responded differently by each ethnic groups. Sundanese and Javanese answered that they disagree as much as $62 \%$ and $50 \%$ respectively, while the Minang people answered 'strongly disagree' as much as $58 \%$. However, some respondents answered 'agree', as many as $25 \%$ by Minang ethnic respondents, $15 \%$ from Sundanese, and $14 \%$ from Javanese. The second statement is about choosing a woman who is cooperative towards their sweet-talking a priority in spouse selection. This statement was both agreed and disagreed by Minang and Sundanese respondents, while the Javanese answered in a variety of manner as can be seen in the graph below. 


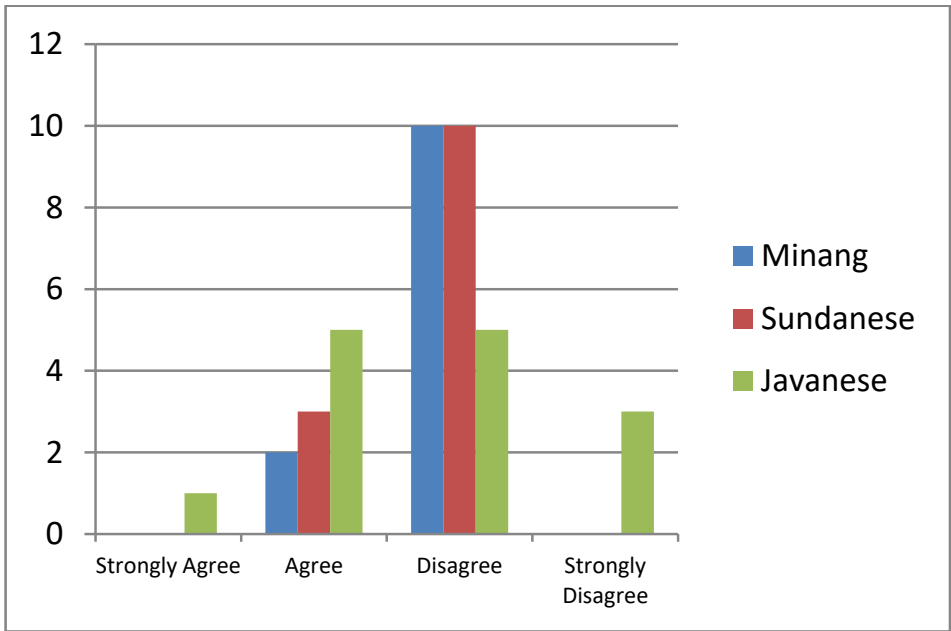

Figure 18: Women who are Cooperative with my Sweet Talks will be My Priority in Choosing a Wife

Source: Designed by the author

The third statement is about the expectation of male respondents after a marriage that it does not matter if later the woman he chooses is not so familiar with his family as long as she loves the respondent. This statement was answered disagree and 'strongly disagree' by respondents by $50 \%$ of the Minang ethnicity groups. Respondents with Sundanese background answered 38\% 'disagree', 31\% 'strongly disagreed', and the remaining 31\% answered 'agreed'. Although $57 \%$ of Javanese respondents answered 'strongly disagree' and 22\% answered 'disagreed', there were $14 \%$ and $7 \%$ of those who answered 'agreed' and 'strongly agree'.

The second variable tested in this study is the family background of the woman who will be his wife. All respondents agreed that the family's origin was their main consideration in choosing a wife as shown in the following graph.

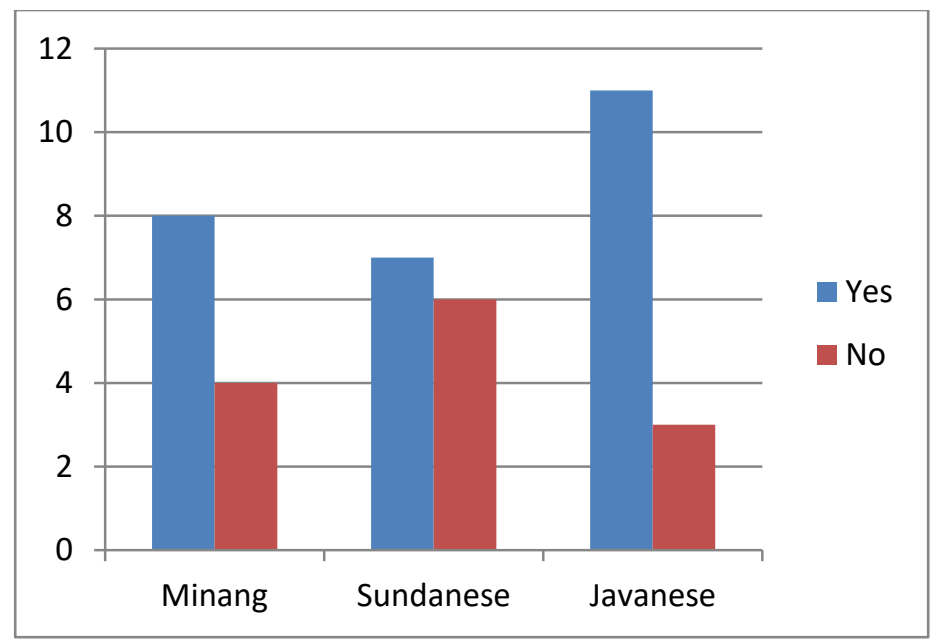

Figure 19: The Origin of her Family Became my Main Consideration in Choosing a Wife

Source: Designed by the author

In support of the above statement, respondents were asked for their opinion on the work of the prospective wife's parents by giving one positive statement and one negative statement. When stated 'Not interested in marrying the daughter of an ustadz or Qur'an teacher, 62\% of the respondents with Sundanese ethnicity answered disagree and the remaining $38 \%$ answered 'strongly disagree'; $58 \%$ of respondents with a Minang ethnicity answered 'disagree' and the remaining $42 \%$ answered 'strongly disagree'; and Javanese respondents gave a balanced answer of 50\% of each answer. On the other hand, most respondents also chose not to agree to marry the son of an official with each answering $62 \%$ of the Sundanese, $58 \%$ of the Minang, and $57 \%$ of the Javanese respondents. Most respondents also agreed not to mind if his future wife came from broken home families (79\% of the Javanese, $69 \%$ of the Sundanese, and 50\% of the Minang). The variety of answers happened when asked about not marrying a woman whose family members had been involved in criminal acts. Most respondents answered 'disagree', but many also answered in 'agreement' such as can be seen in the following graph. 


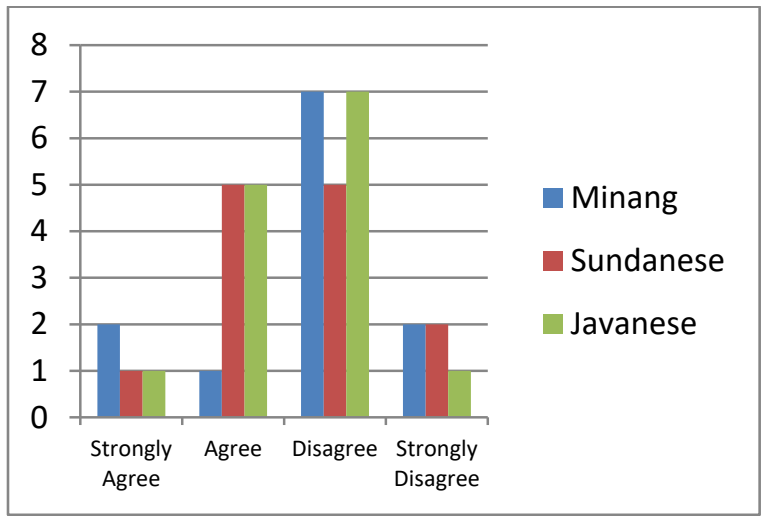

Figure 20: I will not Marry a Woman Whose Family Member had been Involved in a Crime

Source: Designed by the author

The third variable in this questionnaire is the age and status of the prospective wife. Minang and Javanese respondents answered 'agree' to marry a woman whose age was older than himself, which was 67\%, 64\% with the rest only answering to 'disagree'. Even though most answers from Sundanese respondents are 'agreed', which is $46 \%, 15 \%$ of respondents stated that they 'strongly agreed' and 39\% disagreed as can be seen in the following graph.

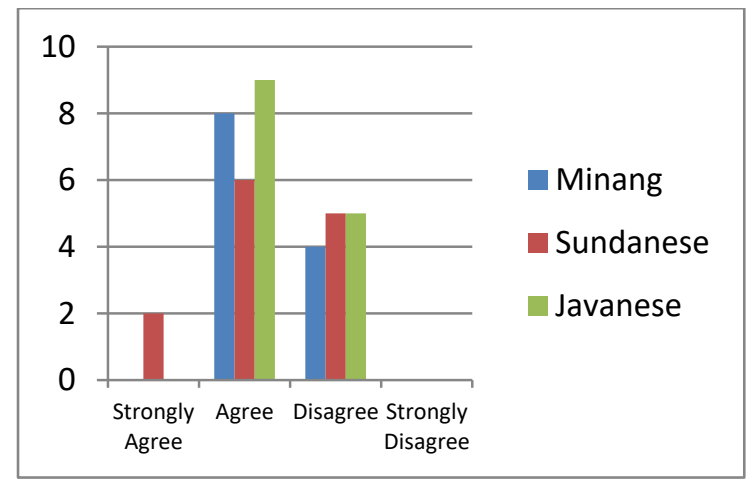

Figure 21: I Am Willing to Marry a Woman Who Is Older Than Me

Source: Designed by the author

When asked if they feel inferior if their future wife is older than him, as many as $71.8 \%$ of respondents said no. Diverse responses were found when respondents were asked for opinions about having no problems in marrying widows while their status was still single. Respondents from the Javanese and Sundanese ethnic groups did not have any problems with that, while respondents from the Minang tribe responded oppositely as can be seen in the following graph.

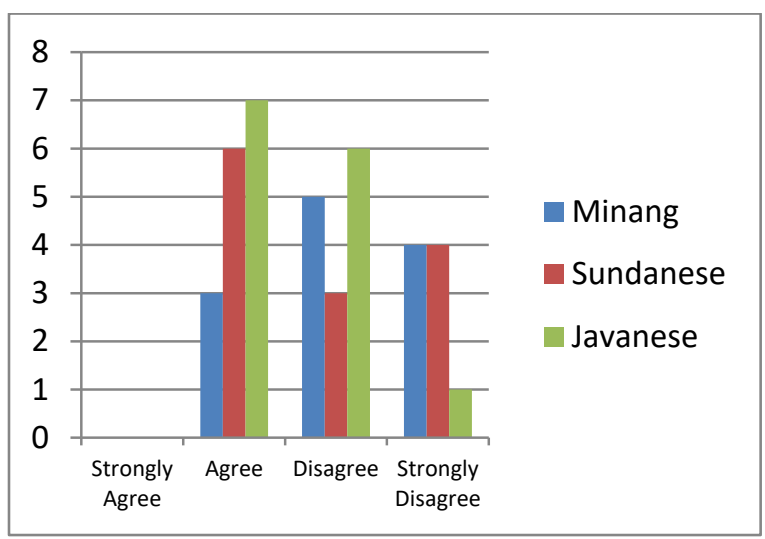

Figure 22: It Doesn't Matter to me if I Marry a Widow While I'm Single

Source: Designed by the author

The fourth variable is wealth. All respondents from the Sundanese ethnic group does not mind marrying a woman who comes from a rich and respected family. It was found that $83 \%$ of the Minang ethnic respondents and $71 \%$ of Javanese respondents agreed, as illustrated in the following graph. 


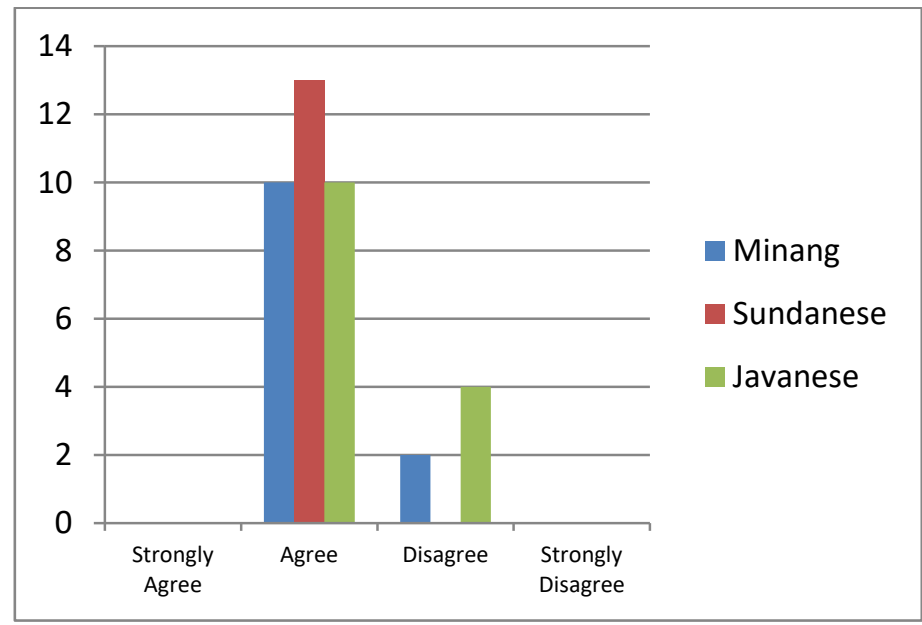

Figure 23: It Doesn't Matter to Me if I Marry a Woman Who Has More Wealth than Me

Source: Designed by the author

Diverse responses were found regarding inferiority from respondents whose prospective wife or her family is richer than him. Most respondents still disagreed with this statement, which meant he would not feel inferior, namely $69 \%$ of the Sundanese, $57 \%$ of the Javanese, and $50 \%$ of the Minang. Some respondents also agreed to this statement, namely $29 \%$ from the Javanese; $25 \%$ of the Minang; and 23\% of Sundanese respondents.

The fifth variable is the height of the bride with a two-point statement asking that respondents would choose a wife whose height does not exceed himself and the respondent will feel inferior if the prospective wife is taller than himself. The first statement was responded favourably by $57 \%$ Javanese respondents and $42 \%$ Minang ethnic groups while $54 \%$ of the Sundanese respondents preferred to disagree. There were also Javanese and Minang respondents who voted against this statement, for as many as $36 \%$ and $33 \%$. The second statement was responded to disagree by most respondents as can be seen in the following graph.

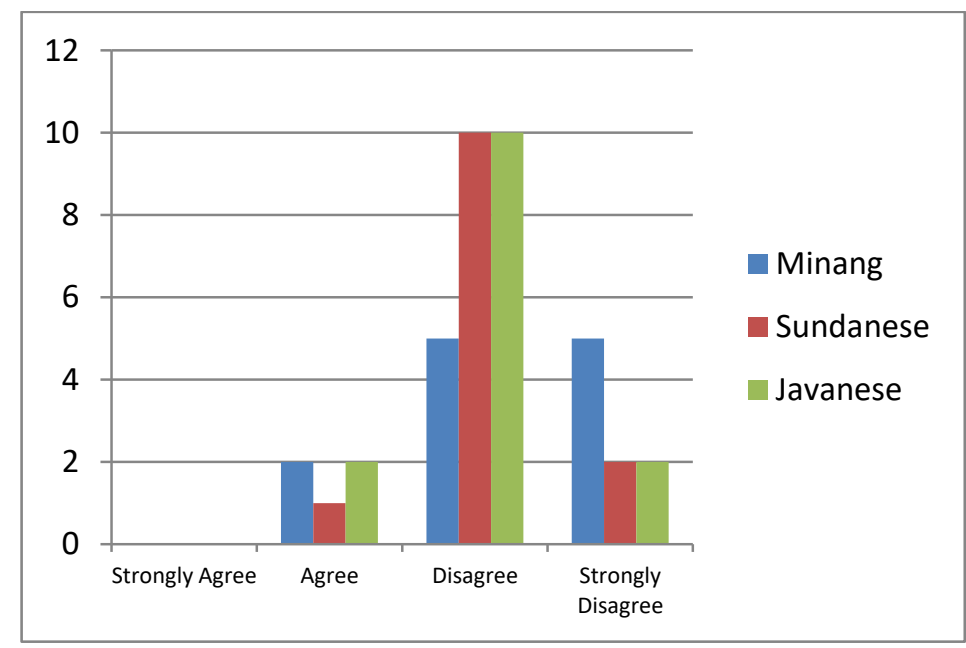

Figure 24: If My Wife is Taller than Me, Then I Will Feel Inferior

Source: Designed by the author

The sixth variable is the prospective wife's career. The three groups of respondents answered disagree if his wife did not help in earning a living, as many as $61 \%$ of Sundanese; $59 \%$ of the Minang tribe; and $50 \%$ of Javanese. They also did not agree not to allow their wives to work even though only part-time was responded to by $67 \%$ of respondents from the Minang tribe; $64 \%$ of Javanese; and $54 \%$ of Sundanese. There are differences in answers when the third statement is submitted to respondents. As many as $57 \%$ of Javanese respondents agree that later their wives should only stay at home and do housework. As many as $62 \%$ of the Sundanese chose not to agree with that opinion. While Minang ethnic respondents each chose $42 \%$ to agree to this.

The future wife's education is the seventh variable measured in this study. In terms of support for the continuation of wife's education, respondents from the Minang tribe preferred to 'strongly agree', as much as 67\% compared to respondents from the Sundanese and Javanese who answered more as much as $69 \%$ and $57 \%$. All respondents also did 
not mind if the candidate has an education level which is higher than himself, with most answering agreed to the statement as in the following graph.

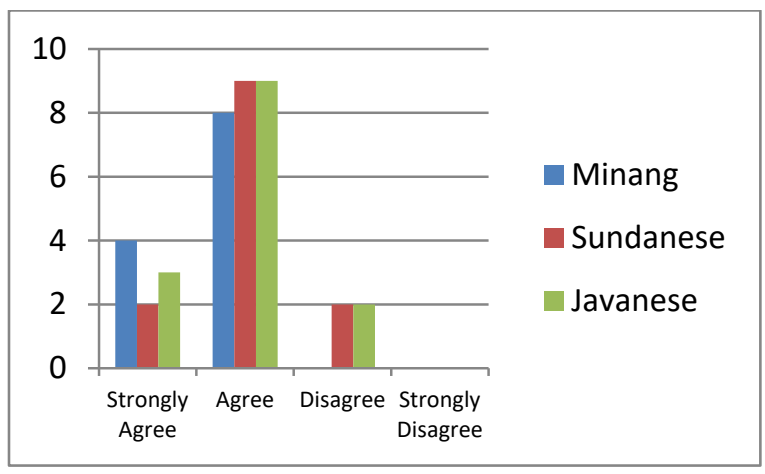

Figure 25: It Doesn't Matter to me if my Wife's Education is higher than mine

Source: Designed by the author

When stated that they would feel inferior if the prospective wife was only a high school graduate, Javanese and Sundanese respondents more often answered disagreed with the percentage $64 \%$ and $62 \%$ respectively while the Minang ethnic respondents chose to 'strongly disagree', for as much as $58 \%$ of the respondents.

The seventh variable is the appearance or beauty of the future wife. The respondents only chose two answers, 'very agree' and 'agree' for the statement that they prefer women who are good at caring for themselves. Most Javanese respondents answered agree (86\%) and the remaining 14 answered 'strongly agree'. Meanwhile, the Minang and Sundanese dominated the 'strongly agreed' answers for as much as $58 \%$ and $54 \%$ and agreed as much as $42 \%$ and $46 \%$ respectively. The choice of white and snub-nosed women to be wives was answered in agreement with Minang and Sundanese respondents with the numbers $67 \%$ and 54\% respectively. However, the agreed response to this statement was only answered by $36 \%$ of the Javanese respondents. Interestingly, almost all respondents agreed to the third statement in this variable, which is to choose a wife who is more beautiful than his family members as in the following graph.

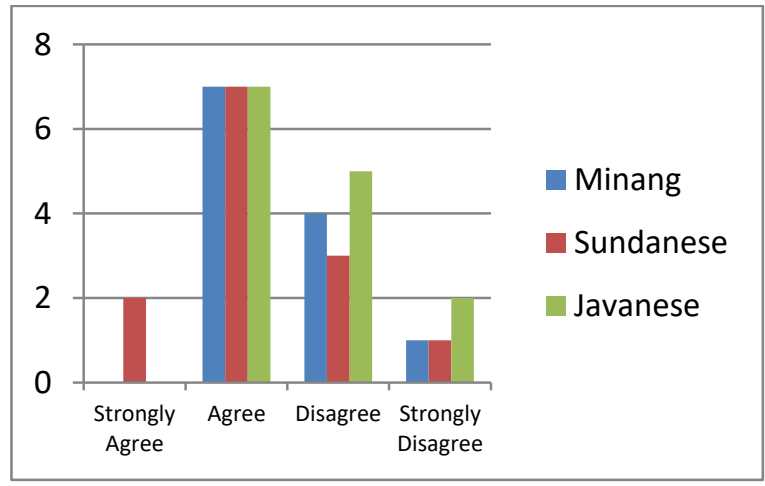

Figure 26: I Want to Marry a Woman Whose Face is More Beautiful than the Rest of My Family

Source: Designed by the author

When a statement was made about women who are often covered in heavy makeup, all respondents responded with disagreement and 'strongly disagree' with the percentage of $69 \%$ and $31 \%$ for Sundanese people; $50 \%$ each for the Minang; and $50 \%$ and $43 \%$ for the Javanese.

\section{b. Marriage Agreement}

As have been mentioned in the result subsection of the female respondents, the statement items in the questionnaire section regarding marriage consent have similarities. Both consisted of two variables with nine statements. These two variables are the introduction phase and forced marriage.

Measurement of the introductory phase is done through five statements that are responded differently by each respondent from the Sundanese, Javanese, and Minang ethnic groups. Among the three, the Sundanese is the group that 'strongly agree' not to have an arranged marriage with someone they don't know at all. As much as $38 \%$ responded negatively to this statement, with $31 \%$ each answering 'agree' and 'disagree'. Meanwhile, the Minang tribe responded to this statement with a percentage of $67 \%$ agreeing, $25 \%$ 'strongly agree', and 8\% 'strongly disagree'; and Javanese responded as much as $43 \%, 21 \%$ 'strongly agreed', and 36\% disagreed. Respondents from Java and Minang mostly wanted to see the future wife in advance, if they had to undergo an arranged marriage for as many as $64 \%$ and $50 \%$ respectively, while 
the remainder 'strongly disagreed'. Meanwhile, 54\% of Sundanese respondents responded 'agreed'; 38\% 'strongly agreed'; and $8 \%$ of them disagreed with this opinion. The introductory process chosen by this male millennial generation is Islamic ta'aruf with the predominance of positive answers from the Javanese and Sundanese while the Minang respondents responded more strongly to agree as shown in the following graph.

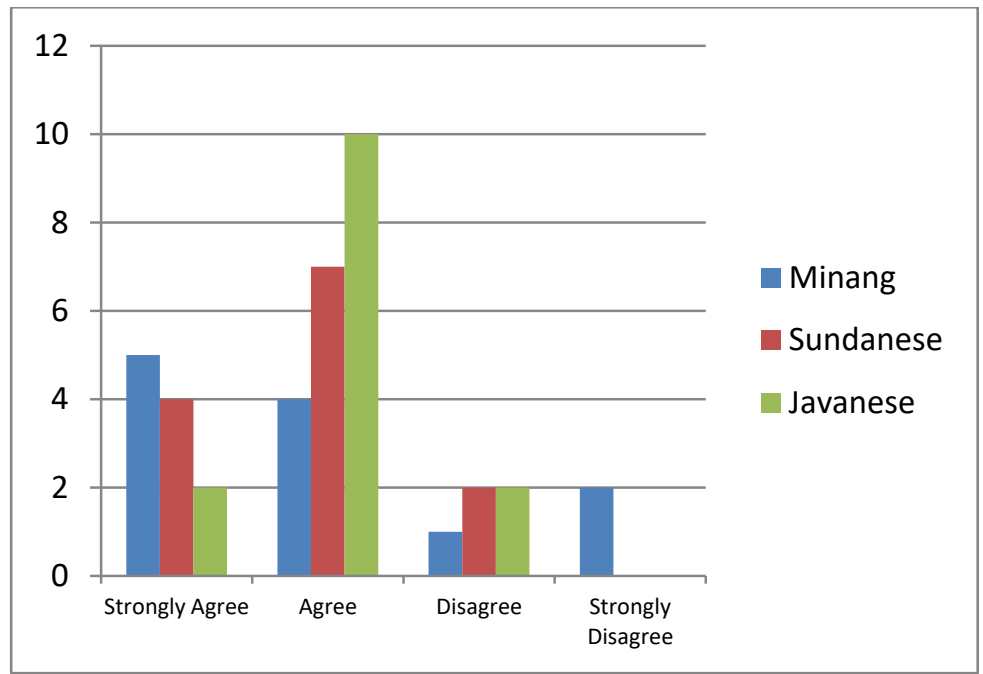

Figure 27: I Chose the Islamic Ta'aruf Procession (During the Introduction, Each Candidate will be accompanied by His Mahram)

Source: Designed by the author

Therefore, male respondents answered that he disagreed with the introductory process through courtship before marriage with a response rate of $57 \%$ from the Javanese, $54 \%$ from the Sundanese, and $33 \%$ from the Minang. During this introductory process, respondents agreed to allow their prospective wives to personally investigate the respondent through respondents' close friends with a percentage of $79 \%$ answers from the Javanese, $62 \%$ from the Sundanese, and $59 \%$ from the Minang.

The second variable measured in this instrument is about forced marriage. Based on the results of the questionnaire, some respondents understood the concept of wali mujbir at 59\%. In their minds, respondents from the Minang and Javanese ethnic groups agreed that the concept of forced marriage was when they could not refuse to marry as much as $67 \%$ and $57 \%$, respectively. This contrasts with respondents from the Sundanese that as much as $46 \%$ chose to be betrothed and are required to marry someone they do not know, as the concept of forced marriage. Each group of respondents also answered that they did not agree if they had to be forced into marriage by their mothers or fathers with a percentage of $72 \%$ of the Javanese; $67 \%$ of the Minang tribe; and $46 \%$ of Sundanese.

\section{DISCUSSION}

On page 67 and 68 of al-Mu'āsharah, Shakūr had written on the issue of mate selection for women and men. He divided his discussion into Ikhtiyāru al ziwāj and Ikhtiyāru al ziwājah or the search for a spouse. If explored further, Shakur had tried to interpret the Prophet's hadith about mate selection, as follows:

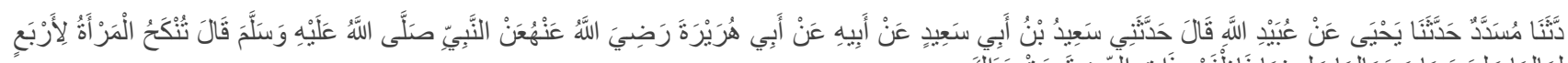

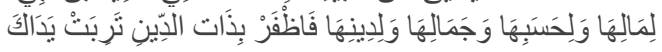

That is, described by Musadad, narrated by Yahya from 'Abdullah who said to tell me Sa'id Ibn Abi Sa'id from Abi Hurairah ra that the Prophet said the woman is married to for four cases. First, her wealth; second, the position of her status; third, because of her beauty; and fourth, because of her religion. Therefore, if you look for a religious woman (of Islam), you will be lucky."

Through this hadith, Shakur then breaks down the profile of men who will be made husbands by women and vice versa, the profiles of women who will be made wives by a man. In his description, Shakur also gave his views on things that could degrade women in choosing a husband, such as forbidding to choose men because of their looks, wealth, and being too generous in giving gifts. These considerations will not be eternal. He is only temporary and entrusted by God whenever He wants. Likewise, with men, Shakūr advised not to marry a woman who is older, taller, and wealthier and has a higher position than himself. Shakur's concern over the last three things is due to his inferiority complex, which will always be under the control of his wife. Meanwhile, older age is a common factor included in the study of health, which mentioned that women's physical limitations are in terms of reproduction. The following is an elaboration of his views. 


\section{The Ideal Types of Men for Women}

Shakūr provided some guidelines for selecting a man for a woman in al Mu'āsharah of the Ikhtiyāru al ziwāj sectionas can be seen in the following quote:

"Maka hendaklah perempuan memandang dan menilik akan laki-laki yang beradab jujur, beragama tetap, sehat badan, tajam pikiran, panjang akal, dan banyak berpengetahuan.

Maka janganlah perempuan terpandang kepada laki-laki karena banyak hartanya, baik rupanya, elok parasnya, dan pemurah pada pemberiannya. Lebih-lebih janganlah dia hendak bersuamikan seorang yang jahat pekerti, kurang sopan, dan lemah memegang agama.

Malahan sewajibnya bahwa ada pilihnya akan orang yang baik, berakhlāqu al karīmah, tinggi budi basanya, manis perkataan dan peribahasanya, yang bertaqwa kepada Alläh, sekufu sepadan dengan dia pada bangsanya, pengetahuannya, dan pada kehormatannya dan kehormatan kaumnya supaya ia mendapat teman yang sejahtera dan pergaulan yang suci zāhir bātịin." (al Mu'āsharah: 68)

"Women should choose men who are honest, religious, healthy, smart, and knowledgeable as husbands. They should not be deceived because he is rich, handsome, and happy to give gifts. Moreover, in choosing a man who is impolite and unreligious.

Choose a good man, has akhlāqu al karimah, speaks kindly, is devoted to God, aligned in terms of position, knowledge, and family honour so that life becomes harmonious."(Al-Mu'āsharah: 68)

It was based on the above guidelines, that the questionnaire was constructed and answered by 72 female Millenials. The results of this research show that they still hold fast to the values that Shakur had written. Although this text originates from Minangkabau, it turns out that Shakur's teachings, which were almost a century ago, still have relevance to the female millennial generation in 2019 of three different tribes, namely the Javanese, Sundanese, and Minang. Female respondents still want a husband who is devout in praying which is marked by their consistency in maintaining prayer times. The sampling of this statement in the questionnaire item is because salat is a type of worship that can be observed by anyone. The consistency of praying in time is also a virtue according to Allah, in QS An Nisā ': 03:

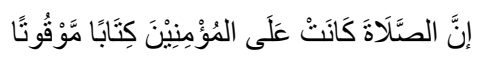

It means, "Surely prayer has a fixed time for believers."

Moreover, the hadith also disclosed that praying at the beginning of time is a noble deed as listed in hadith number 139 of the book 'Ibādah al Aḥkam by As Sayyid' Alawi bin 'Abbas al Mālīkìy. The translation of this hadith is: "From Ibn Mas'ud Radliyallaahu 'anhu that the Prophet sallallaahu' alaihi wa Sallam said: "The noblest act is praying at the beginning of time." The hadith narration was authentic according to Tirmidzi and Hakim. The originator was BukhariMuslim."

Another indicator to measure obedience is the performance of various sunnah such as sunnah fasting or charity. In addition to these additional acts of worship as a form of maintaining good relations with Allah, Shakur also emphasizes the importance of morality as a form of maintaining good relations among humans. The variables 'honest' and 'wise' very much support the morality variable that is contained in this research. In the 'honest' variable, the three ethnic groups responded with the desire to have a husband who is true with his words and deeds. They also very disliked men who liked to argue to cover up their lies. In this section, the value of honesty that was instilled by Shakūr in alMu'äsharah is still held firmly by the female generation of Millenials.

The millennial generation of the three ethnic groups also has similarities when choosing a mate based on their physical health. All three agreed that a good diet is an indicator of their health. This can be observed clearly when the dish is served at a banquet or a selection of places to eat. Another observance is on smoking habits. Almost all respondents gave a similar response, namely choosing to dislike it. Certainly, everyone needs clean air as have been proposed also by the government through their public service campaigns that smoking can kill anyone. The controversy regarding the smoking ban continues to this day. But the sample from this study was more interested in men who do not smoke.

An interesting difference in opinion is found in this study. Although all respondents agreed to choose men who speak firmly and clearly, it turns out that all three ethnic groups have different views in terms of desirability in following the opinion of their partner. Respondents from the Minang and Javanese tribes like men who follow their opinions even though these men have other opinions. This viewpoint has pros and cons. If this were done continuously, it would certainly cause selfishness, of which the man would become uncomfortable with the situation. Meanwhile, respondents from the Sundanese tribe preferred not to agree to do so even though some of them agreed. However, back to the key message, in the beginning, a partner's positive intention must be followed, especially since the husband is a leader in the household. However, a husband might not always be in the right position. It is certainly recommended for the wife to give a better opinion and she must be distinct from her argument. 
In terms of conversation, it was found that respondents of the Sundanese and Minang ethnic groups do not like men who dominate the conversation. Unlike the case with respondents from Javanese who chose to like it. This may be caused by cultural backgrounds and teachings that have been passed down from generation to generation, taught by the ancestors of each tribe. This condition eventually formed a different character between the three. Still, in the conversation section, it turns out that the topics of technology and politics were favoured by the female millennials from a male. This will show one's breadth of knowledge because the two topics require one to be updated in the realm of science and information. The topic of technology was more favoured by Sundanese respondents, followed by the Javanese and Minang respondents. Meanwhile, the talk of politics was more favoured by Sundanese and Javanese while Minang ethnic respondents do not prefer it very much. The latter may be affected by current events in 2019 , such as the heated Indonesian presidential election. However, naturally, the younger generation must pay attention to the political and scientific situation because it is related to the country's resilience which will be at stake in the future. For this reason, all respondents prefer men who are fond of reading so that they can share knowledge and broaden their horizons.

In terms of the morals of a man, all respondents choose a man who can respect her family as he respects his own. This is related to making good relations between families. The difference in the kinship system of the Minang with the Sundanese and Javanese does not make a difference in terms of family appreciation in such that harmony can be created. Besides, respondents were also asked for their opinions about men how they gaze when talking to women. Today's women prefer to maintain eye contact in a conversation. Of course, this depends on the topic of the conversation being carried out because not all must be generalized. However, because in this context is the choice of a mate, of course, this needs to be considered to determine the character of the prospective husband. All respondents prefer men who keep eye contact while talking, even respondents from the Javanese and Sundanese chose to 'strongly agree' with this statement. The development of the times and the extent of the association brought about a change in the perspective of young Indonesian Muslims. However, they did not agree with men who have many female friends, with many Javanese valuing it 'strongly disagree'. They also 'strongly disagree' if men often hold meetings with their friends at night clubs. This response is different from their opinion of making eye contact with a male. On one hand, they want men who are not associated with women and nightclubs but want men to be friendly to them. This occurrence may need to be addressed by re-instilling Islamic values because wise people say the eye is the window to the heart.

However, appreciation needs to be given to these female respondents regarding the concept of guarding themselves against crimes that might arise from men of bad character. They agreed not to join hands with a man who was not yet her husband as is commonly found today. They also do not like discussions that contain porno Graph elements because it is harassment against women. When asked about corruption, they also agreed not to want their men to do it even in a pressured situation.

When asked for opinions about the looks and appearance of their prospective husband, the females, humanely, want men who are handsome and have proportional height and weight. Minang respondents answered more positively with these criteria, but this did not apply to Sundanese and Javanese respondents. The Sundanese respondents turned out to be choosing men who were handsome and good looking to be their husbands. Meanwhile, Minang and Javanese respondents did not consider it.

So is the case with wealth and gifts given by men. Most female respondents from the three ethnic groups do not prefer men that use gifts to win hearts as husbands even though a small portion of them still prefers otherwise. Minang respondents view that men who like to give gifts have an ulterior motive. But this does not mean so for Javanese and Sundanese respondents who choose to disagree with this opinion.

Different opinions were expressed by Sundanese respondents. They view luxurious gifts given by a man is a form of appreciation for her and will accept it. Meanwhile, Javanese and Minang respondents were consistent in disagreeing with this opinion.

In this case, these female millennials seem to have strayed from the frame written by Shakūr in al Mu'āsharah. Shak ūr reminds women not to be lured in the facade of a handsome or good looking man. But respondents from the Minang and Sundanese tribes consider this in choosing a husband. Only Javanese respondents chose not to prioritize this. The same indicator is also found when considering men who are happy to give gifts. Shakūr reminded women to be careful with these types of men. Although all agreed not to be too attracted to wealth and the pleasure of giving gifts, it turns out that Sundanese respondents chose to be happy with luxury gifts as a form of appreciation and does not consider men who give them to have ulterior motives. Respondents from the Javanese and Minang tribes are consistent with not liking it. In this case, it turns out that the millennial generation of Java and Minang followed the values instilled by Shakur in choosing a husband.

\section{The Ideal Types of Woman for Men}

Shakūr gave several recommendations for men who is in search for a spouse in the $67^{\text {th }}$ page of al-Mu'āsharah. His advice is as follows:

"Pihak laki-laki hendaklah berikhtiār memilih yang akan bakal istrinya daripada perempuan [yang] memenuhi adab sopan, baik akhlak, budi pekerti, dan berlaku perangai yang terpuji. Yaitu diambil dari keturunan yang suci bersih. Dari 
asal usul yang mulia, keluaran dari pergaulan yang sopan, dari antara ibu bapa yang setia, dari famili dan ahli orang ternama, anak cucu orang baik-baik”. (al Mu'āsharah: 67).

"A man should try to find a spouse who has good character, behaves politely and praiseworthy, who comes from good families and parents that do not have a bad predicate in the eyes of society." (al-Mu'äsharah: 67).

Courtesy and good manners can be recognized by how one speak, dress, and socialize. In general, male respondents prefer a woman who speaks softly, friendly, and habitually smiles. They also fancy women who take an interest in their conversation. However, respondents from the Minang tribe were not too fond of women who maintain eye contact during a discussion. This viewpoint is contrary to those of the Javanese and Sundanese respondents. This difference in perspective is thought to be caused by the cultural setting between the three tribes.

The way a woman dresses is also a main consideration for all respondents in choosing a wife. Almost all respondents did not agree to choose women that dress revealingly as wives. For this reason, they prefer women who are dressed in a syar' $i$ manner because they are more likely to safeguard themselves. Even though this kind of opinion cannot be generalized, but Islam prescribed women to cover their aurah and to cover themselves with a jilbab till their chest.

In terms of the relationships with family, respondents do not agree if the prospective spouse is not able to put themselves well amongst his family members. Male respondents still want his future wife to be close to their family members. When asked about the choice to prioritize either the mother or wife, the male respondents prefer to prioritize the interests of their mother. It turns out that the values of modernization that are developed in this current era does not erode their responsibilities as a son. Another finding in this section relates to the sweet talks made by the male respondents. The Sundanese and Minang tribes agree not to make women who respond cooperatively to their sweet talks as wives. Meanwhile, Javanese respondents have a balanced answer, some of them choose to agree and some others choose not to agree with such an opinion. However, all respondents still hope to have a spouse who has a better character than him.

Family background is also the male respondents' consideration in choosing a wife. Family background such as having divorced parents or broken home is not a concern for them. However, some of these male respondents were sceptical about choosing women whose family members were involved in criminal activities. This will certainly have an impact on the good name of the family that they will develop later and humanly this is certainly common.

In this case, the values of Shakur for choosing a wife who has good morality and comes from a good family is still used by the millennial generation. Problems regarding criminal acts that involved family members or divorced parents did not significantly affect them.

Still, on the same topic, Shakur advised as follows:

Kata orang pandai-pandai, Ba'ḍa ul hukamā i, kalau engkau memilih istri, carilah yang kurang daripada engkau pada empat șifat: kurang umurnya, kurang hartanya, kurang tingginya, dan kurang bangsanya daripada engkau. Kalau tidak mungkin engkau cari rendah pada pemandangannya. Dan carilah yang lebih dia daripada engkau pada empat perkara: perangainya dan akhlaknya, rendah hatinya dan sopannya, adab dan tertibnya, dan perawakannya serta jombangnya (al Mu'āsharah: 67)

"A wise man said, look for a woman who has four shortcomings for you: less age, less wealth, less height, and less (lower) position than you. If not, look for four advantages: higher morale, more humble, have a politer language, and better looking than you. (al Mu'āsharah: 67)

In this section, Shakur's message is quite clear, that is to look for women who have four shortcomings and four advantages. The four shortcomings are not older, not richer, not taller, and have a lower position in society. These four shortcomings stated by Shakur are not without any purpose. He wants men to feel respected and not bullied by their friends of his choices in such that he becomes inferior. Perhaps this applies to the Minangkabau people at the time this text was written. With the development of different times and cultural settings, this message slightly fluctuates.

When asked about the marriage status of the prospective wife, Minang respondents prefer not to marry widows. This is different from Javanese and Sundanese respondents who have no problem marrying a widow while their status is still single. Regarding age, in general, they are willing to marry a woman who is older than herself and will not feel inferior about it. Likewise, in consideration of a woman's height, respondents from the Javanese and Minang tribes prefer a wife whose height does not exceed him, while respondents from the Sundanese chose the opposite. Most Sundanese respondents chose a wife whose height was higher than theirs. However, in general, all respondents will not feel inferior if their future wife is taller than him. This is a contrast in regards to the prospective wife's wealth. Although they do not want to marry a woman who comes from a wealthy and respected family, they have no problem if they would later get a wife who is richer than him. Even respondents from the Sundanese tribe answered $100 \%$ for this and a small portion of the Javanese and Minang tribes answered that this would cause problems. It is important to note, the males apparently will not feel inferior if the prospective wife and family are richer than him. In this section, Shakur's argument is indisputable that with a prospective wife who is older, taller, and richer and respected will make them inferior. But in the 
latter problem, men indeed need to think about these factors carefully, because some would feel disturbed on the dominance of the wife's family.

The choice of a wife based on morals or manners, courtesy, and appearance is Shakur's next concern. The problems of morality, manners, and politeness of a woman have been mentioned before and such are the priority of these millennial men in mate selection. Another consideration is the appearance or beauty of a woman. All respondents agreed to choose a beautiful and smart wife to take care of themselves and even they would choose a woman whose beauty exceeded other family members. The type of beauty they chose turned out to be natural beauty because they were not happy with women who wore excessive cosmetics.

\section{Perceptions about Arranged Marriages and Forced Marriages}

In terms of arranged marriages, the majority of respondents from the three ethnic groups, both male and female, are not willing to have an arranged marriage with someone they do not know. If they still need to go through one, they at least want to see their future spouse first in order to create interest or 'chemistry'. This is in line with what Shakur had advised, namely:

Telah berkata setengah orang pandai-pandai, tiap-tiap perkawinan yang terjadi dengan tiada mengetahui kedua belah pihak akan temannya atau jodohnya, maka akhirnya menurut biasa, menjadi penyesalan dan duka cita (al Mu'āsharah: 67).

"A wise man said, if the prospective husband and future wife are not introduced to each other before marriage, then the marriage will end in disappointment." (al Mu'āsharah: 67)

However, in the introduction process, all respondents agreed not to date. They would choose the Islamic way of introduction to orta'aruf. In this acquaintance method, the two candidates will meet while accompanied by a mahram. This is in line with the research conducted by Hidayat and Wardana(2018) on young people in Yogyakarta. They chose an arranged marriage that is following Islamic law to avoid immoral acts. They also involved parents in making decisions so that they could get a blessed marriage and also Allah's blessing (Hidayat \& Wardana, 2018). In the ta'aruf procession, the information obtained comes from the personal or social environment of each candidate. Based on the results of the questionnaire, it turns out they allow their future wives or future husbands to get to know them intensely through their close friends. The results that have been obtained will also support Asyari and Abid, (2016) research on the actions carried out by the Tarbiyah Movement to introduce the procedure for choosing a suitable mate following Islamic law. Even in this group, every person who will be married must prepare well and be guided by their assistants, whom, alongside their parents, will have the final say in decision making (Asyari \&Abid, 2016).

Because the parents were involved, respondents were also asked for their opinions on the imposition of marriage which in Islam could be carried out by the wali mujbir. Most of the female respondents did not know the term wali mujbir while the male respondents stated otherwise. Wali Mujbir is the father or grandfather of the woman who has the right to impose marriage on her child or granddaughter with heavy requirements. Among the requirements are that the woman is believed to be a virgin, for the two candidates to be equal in some matters (sekufu), and that the two families have good relations nor have ever been involved in a dispute (Ma'mun, 2016). Based on the questionnaire, the millennial generation disagrees with the concept of forced marriage. For the millennial generation of Sundanese men and women, forced marriage is being asked to marry someone whose appearance and stature they do not favour. For the millennial male and female Minang, forced marriage is a condition where he cannot refuse to marry. Meanwhile, millennial Javanese men and women have different opinions. The concept of forced marriage for Javanese female respondents is the same as Sundanese respondents and the concept of forced marriage for Javanese male respondents is the same as Minang respondents.

After reading the results of the questionnaire, it was found that almost all respondents were not willing to be forced in marriage by their father or mother except the female respondents from the Minang tribe. They were the only ones who are willing to be forced marrying a man that their parents choose. For some Minang women, such acceptance is normal, because before marriage they have been taught to be obedient to their big family. In the past, what determined this coercion was the matrilineal family without involving the father. But in its development, the father took more positions in his core family. This is what Shakūr had advised at the end of page 68 which reads, "Hanya Dalam agama diehards kepada bapanya dengan sharat-sharaț" (al-Mu'āsharah: 68). However, the statement to make religion the basis for choosing a husband must be the father's priority, so that his daughter's life is filled with happiness, both in this world and the Hereafter, as Shakur had written below:

Orang pandai-pandai, Ba'ḍa ul hukamā $i$, ada berkata, 'Persuamikanlah ahli engkau dengan seorang laki-laki yang taqwa kepada Allāh, yang tahu akan aturan agamanya. Niscaya adalah nanti jika ia sayang kepada istrinya." (al Mu'āsharah: 68).

"A wise man said, 'Marry your daughter to a man who is devoted to Allah and knows the laws of his religion. Thus, he will love his wife sincerely.' (al-Mu'äsharah 68) 
This culture is likely to have similarities with the Indian culture, who is also famous for their arranged marriages. Indian communities like Chettiars who have migrated to Malaysia since long ago, still maintain this culture. Despite the development of times, technology, and the extent of the social environment that can be easily reached, it turns out that they still adhere to the arranged marriage by their families (Somasundaram, 2019).

\section{CONCLUSION}

The results showed that the millennial generation of women wanted a prospective husband who is devout, honest, ablebodied, and wise in his opinion, responsive, and listens to the opinions of others. Also, they are more pleased with men who have a good character such as being able to protect themselves from associations that damage the good name, respect others, and avoid conversations that are harassing women. In terms of looks, Sundanese respondents prefer mates who are handsome and have a nice look, while Minang respondents choose men who have attractive posture and physical features. The Javanese respondents chose not to make both considerations. In the case of gifts from men to win hearts, all respondents agreed not to like them. However, gifts received for Sundanese respondents elaborated as a tribute to her. Minang respondents stated that men who were happy to give gifts had ulterior motives while the other two tribes said they were not.

On the other hand, the male millennial generation wanted a well-mannered wife emanating from soft speech, dressing modestly, and being wise in social relations. They also choose women who come from good families. However, some of them can still tolerate marrying women from broken home families or whose family members have been involved in criminal activities. In terms of age, wealth, and height, Shakur suggested that men should not choose an older, richer, and taller wife than himself. It turned out that the male millennial generation chose the opposite. Javanese and Sundanese respondents were willing to marry a widow even though he was still single. In matchmaking, all millennials do not agree to an arranged marriage with someone they do not know at all. If it had to be an arranged marriage, at least they could go through an introductory process or, ta'aruf, an introduction that is following the Islamic law. All respondents, except the female respondent from the Minang tribe, refused to be married by force both by their mother and father.

It can be concluded that the mate selection values written by Shakur in al Mu'äsharah are still largely acceptable in modern life today by the millennial generation of women from the Sundanese, Javanese, and Minang tribes. Choosing a spouse with characteristics that are Islamic, physically, and mentally healthy will certainly produce a productive family. From a productive family, of course, it will create a strong civil society morally and financially.

\section{LIMITATION AND STUDY FORWARD}

This research has some limitations which must not be overlooked. The subjects of this study were males and females from three tribes of Indonesia; future research must include other tribes and replicate this study to get more refines results. Moreover, this study investigated the preferences of males and females in terms of some physical attributes, financial status, ethnicity, education, family background, marital status, etc. Future research must investigate the preferences of individuals in terms of factors that are not part of this study. In short, this research must continue with a wider sample and wider variables to measure this case from various aspects.

\section{ACKNOWLEDGMENT}

We would like to express the appreciation to the research participants for their response and feedback throughout the data collection process. Thank you so much. This study is an original work carried out by the researchers and no financial or non-financial support is received from any party for formulating this study.

\section{AUTHORS CONTRIBUTION}

Yulfira Riza worked on the initial write-up and data collection. Titin Nurhayati Mamun and Syarief Hidayat performed data collection, analysis, and interpretation. Ikhwan refined the initial draft and performed the language proofreading on the final draft.

\section{REFERENCES}

1. Al-khresheh, M., Khaerurrozikin, A.,\& Zaid, A. (2020). The efficiency of using pictures in teaching speaking skills of non-native Arabic beginner students. Universal Journal of Educational Research, 8 (3), 872-878. https://doi.org/10.13189/ujer.2020.080318

2. Ammon, U. (2004). Sociolinguistics: An international handbook of the science of language and society. (2nd ed.).Berlin: Walter de Gruyter.

3. Arikunto, S. (2013).Research procedure: A practical approach. Jakarta, Indonesia: PT Rineka Cipta.

4. Askuri, A., \& Kuipers, J. C. (2019). An orientation to be a good millennial Muslims: state and the politics of naming in islamizing Java. Indonesian Journal of Islam and Muslim Societies, 9(1), 31-55. https://doi.org/10.18326/ijims.v9i1.31-55

5. Asyari, S., \& Abid, M. H. (2016). Expanding the Indonesian Tarbiyah movement through Ta 'âruf and marriage. Al-Jami'ah: Journal of Islamic Studies, 54(2), 337-368. https://doi.org/10.14421/ajis.2016.542.337- 
$\underline{368}$

6. Bell, T.(2005). Behaviors and attitudes of effective foreign language teachers: Results of a questionnaire study. Foreign Language Annals, 38(2), 259-270. https://doi.org/10.1111/j.1944-9720.2005.tb02490.x

7. Blachman, B., Tangel, D., \& Ball, E. (2004). Combining phonological awareness and word recognition instruction. Perspectives, The International DyslexiaAssociation, 24(9), 12-14.

8. Brown, A. (2011). Relationships, community, and identity in the new virtual society. Futurist, 45(2), $29-34$.

9. Bryden, L. T. (2017). Online dating applications and the uses and gratifications theory. Ewu Digital Commons, Eastern Washington University.

10. Bunton, T. E., \& Brewer, J. L. (2012, October). Discovering workplace motivators for the millennial generation of IT employees. In Proceedings of the 1st Annual conference on Research in information technology, pp. 1318. https://doi.org/10.1145/2380790.2380795

11. Cook, V. (1991). Second language learning and language teaching. London: Edward Arnold.

12. Fairclough, N. (1989). Language and power (1st ed.). Longman Inc.: New York.

13. Godwin-Jones, R. (2005). Messaging, gaming, peer-to-peer sharing: Language learning strategies \& tools for the millennial generation. Language learning \& technology, 9(1), 17-22.

14. Hamers, J. F., \& Blanc, M. (2000). Bilinguality and bilingualism. Cambridge: Cambridge University Press. https://doi.org/10.1017/CBO9780511605796

15. Heath, J. (2005). The Arabic language and national identity: A study in ideology. Journal of Linguistic Anthropology, 15(2), 281-283. https://doi.org/10.1525/jlin.2005.15.2.281

16. Hidayat, T. T., \& Wardana, A. (2018). Ta'aruf and efforts to build Islamic matchmaking among Young Muslim Couples in Yogyakarta. E-Societas, 7(7), 1-22.

17. Kao, A. (2016). Tinder: True Love or a Nightmare? Scholar Commons, 16, 1-18.

18. Ma'mun, T. N. (2016).Women and actualization of marriage law in the text of the book of Fi Hukmi an marriage of Imam Syafi'i school of work by Abdullah Bin Ibrahim.Bandung, Indonesia: UNPAD Press.

19. Mishra, S., Monippally, M. M., \& Jayakar, K. P. (2013). Self presentation in online environments: a study of Indian Muslim matrimonial profiles. Asian Journal of Communication, 23(1), 38-53. https://doi.org/10.1080/01292986.2012.717094

20. Pujasari, L. S., \& Mardianti, P. (2016). Interpersonal communication between husband and wife through online dating taaruf. Journal of Communication Research, 19(2), 165-178. https://doi.org/10.20422/jpk.v19i2.89

21. Riza, Y., \& Sandora, L. (2019). Shekh Abdul Lațîf Shakūr's manuscript dunia perempuan and woman representation on man's view. In 2nd Internasional Conference on Culture and Language in Southeast Asia (ICCLAS 2018), Atlantis Press. https://doi.org/10.2991/icclas-18.2019.22

22. Saadia, R. F. (2015). The exploratory study on the relationships among Taiwanese college student's construallevel, gratitude and intimate attachment. International Journal of Humanities, Arts and Social Sciences, 1(2), 92-100. https://doi.org/10.20469/IJHSS.20001

23. Saifullah, M. (2018). Beyond Moslems panics: An exploration upon instagram matchmaker in Indonesia. Harmoni, 17(2), 341-351. https://doi.org/10.32488/harmoni.v17i2.301

24. Sintang, S., \& Hambali, K. M. (2018). Double marginality in new Muslims' relationship with born Muslims and non-Muslims. International Journal of Humanities, Arts and Social Sciences, 4(3), 150-159. https://doi.org/10.20469/ijhss.4.10004-3

25. Somasundaram, R. (2019).Arranged marriage in Malaysia among millennial nagarathar nattukottai chettiars. The University of Arizona. Retrieved from http://hdl.handle.net/10150/626608

26. Summers, N. (2014). The truth about tinder and women is even worse than you think. Bloomberg. Retreived from https://bloom.bg/2S1OKWr

27. Tiller, R. (2018). Navigating Muslim identity and customs in online dating. Intersect, 12(1),1-11.

28. Wahyudi, R. (2012). Language and Identity: A case study on matchmaking Discourse (Javanese and Islamic Perspectives). Language Discourse \& Society, 1(2), 107-117.

29. Wekke, I. S. \& Hamid, S. (2013). Technology on Language Teaching and Learning: A Research on Indonesian Pesantren. Procedia - Social and Behavioral Sciences, 83, 585-589. https://doi.org/10.1016/j.sbspro.2013.06.111

30. Yang, S. C., \& Chang, C. M. (2017). Transnational marriage in Taiwan: Challenges faced and adaptation strategies adopted in experiencing a different culture. International Journal of Humanities, Arts and Social Sciences, 3(4), 142-147. https://doi.org/10.20469/ijhss.3.20001-4 